\title{
Constituents of "teabacco": A forensic analysis of cigarettes made from diverted nicotine replacement therapy lozenges in smoke-free prisons
}

Courtney Mitchell ${ }^{1}$

Cheneal Puljević* $*^{2,3,4}$

Ross Coomber ${ }^{2,5}$

Alan White ${ }^{1}$

Sarah L. Cresswell ${ }^{1}$

Jasper Bowman ${ }^{1}$

Stuart A. Kinner $2,6,7,8,9,10$

${ }^{1}$ School of Environment and Science, Griffith University

${ }^{2}$ Griffith Criminology Institute, Griffith University

${ }^{3}$ Queensland Alcohol and Drug Research and Education Centre, School of Public Health, The University of Queensland

${ }^{4}$ Centre for Health Services Research, Faculty of Medicine, The University of Queensland

${ }^{5}$ Department of Sociology, Social Policy and Criminology, University of Liverpool

${ }^{6}$ Centre for Adolescent Health, Murdoch Children's Research Institute, University of Melbourne

${ }^{7}$ Melbourne School of Population and Global Health, University of Melbourne

${ }^{8}$ School of Public Health and Preventive Medicine, Monash University

${ }^{9}$ Mater Research Institute-UQ, The University of Queensland

${ }^{10}$ Netherlands Institute for the Study of Crime and Law Enforcement

*Corresponding author: c.puljevic@uq.edu.au

This is the author manuscript accepted for publication and has undergone full peer review but has not been through the copyediting, typesetting, pagination and proofreading process, which may lead to differences between this version and the Version of Record. Please cite this article as doi: $10.1002 /$ dta.2471

This article is protected by copyright. All rights reserved. 


\begin{abstract}
Background: Following the implementation of prison smoke-free policies, there have been reports of prisoners creating substitute cigarettes made from nicotine replacement therapy patches or lozenges infused with tea leaves ("teabacco"). No studies have analysed the chemical constituents of teabacco made from nicotine lozenges, so as to document any potential related health hazards.
\end{abstract}

Method: Teabacco samples were made by a participant who reported creating teabacco while incarcerated in a smoke-free prison in Queensland, Australia, and the process was video-recorded for replication in a laboratory. A simple linear smoking system captured the teabacco smoke for analysis. Inductively coupled plasma optical emission spectroscopy (ICP-OES) was used to analyse elemental composition and gas chromatography coupled with a mass spectrometer (GC-MS) analysed the captured smoke using the National Institute of Standards and Technology mass spectral library.

Results: Analyses determined that quantities of copper, aluminium and lead concentrations, and levels of inhaled total particulate matter, were above recommended guidelines for safe ingestion. Analysis of teabacco smoke using GC-MS identified potentially toxic compounds catechol and nicotine. However, our findings show that smoking this form of teabacco is less harmful than smoking teabacco made from nicotine patches, or smoking traditional tobacco cigarettes.

Discussion: Considering the limited potential health harm of smoking teabacco made from lozenges, and that nicotine lozenges represent the only form of smoking cessation support for individuals entering smokefree prisons, we caution against the removal of nicotine lozenges from Queensland's prisons, at least until further research directly establishes health harms associated with this form of teabacco.

Keywords: Smoke-Free Policy, Prisoners, Nicotine, Tobacco Use Cessation Products 


\section{BACKGROUND}

Smoke-free policies are increasingly being implemented in prisons around the world in response to high levels of tobacco use among people who cycle through prisons, ${ }^{1-3}$ high levels of exposure to secondhand smoke among non-smokers, ${ }^{4,5}$ and risk of litigation from those exposed to second-hand smoke. ${ }^{4,6}$ Such policies have been introduced in prisons in Canada, ${ }^{7}$ most states of the United States (US), ${ }^{8}$ several European countries, ${ }^{2,9}$ New Zealand, ${ }^{10}$ and in England and Wales. ${ }^{9}$ In Australia, complete smoke-free policies have been introduced in all prisons in the Northern Territory, Queensland, Tasmania, Victoria, and New South Wales. ${ }^{11}$

While evidence from the US shows that these smoke-free policies have significantly improved the health of people in prison, ${ }^{3,12}$ these policies have resulted in some unintended consequences. One such example is the diverted use of nicotine replacement therapy (NRT), where prisoners are substituting traditional cigarettes by creating their own cigarettes out of NRT supplied by correctional authorities. This practice has been reported in smoke-free prisons in Australia, ${ }^{13}$ New Zealand, ${ }^{14}$ and in the United Kingdom. ${ }^{15}$ The few published studies ${ }^{13,14,16,17}$ reporting diverted use of NRT in prison describe how prisoners first mix provided nicotine patches with tea leaves - earning this substance the nickname "teabacco" - then roll the mixture in paper (typically from standard-issue prison Bibles or toilet paper tissue), and finally ignite the created cigarettes using batteries or electronic appliances. Two qualitative studies with Australian prisoners have described the use of teabacco made from nicotine patches, ${ }^{13,16}$ and one study has analysed the chemical constituents of teabacco made from tea leaves and nicotine patches. ${ }^{17}$ This forensic analysis found that smoking teabacco cigarettes made from nicotine patches released nicotine, as well as harmful toxins formaldehyde, acetaldehyde, acrolein, toluene, xylene, and heavy metalsproviding clear evidence for the potential of this form of teabacco to result in short- and long-term health harm. Participants in both qualitative studies also described fellow prisoners experiencing negative health effects as a result of smoking teabacco made from nicotine patches, including nose bleeds, seizures, and strokes. $^{13,16}$

The state of Queensland in Australia is one jurisdiction in which anecdotal reports of teabacco use in prison have emerged. In Queensland, a smoke-free policy was implemented in all prisons on the $5^{\text {th }}$ May 2014, and prisoners were provided with a free 12-week supply of nicotine patches (consistent with standard community practice). Nine months later, this was reduced to one week of free patches provided to all people entering prison. Unsubstantiated reports of teabacco made from nicotine patches emerged in the media, ${ }^{18}$ 
leading to Queensland correctional authorities removing all nicotine patches from their facilities. However, despite the withdrawal of formal NRT provision, prisoners are still able to buy nicotine lozenges (but not patches) from the prison shop in most prisons. It became known to us that prisoners in Queensland then began creating teabacco from nicotine lozenges instead, with this practice also reported in the media in other states. ${ }^{19}$ There are no studies reporting the health effects of smoking teabacco made from nicotine lozenges. The aim of this study is to identify the chemical constituents of teabacco made from nicotine lozenges, so as to document any by-products that may constitute health hazards for smokers of this form of teabacco.

\section{METHOD}

\section{Recruitment}

During data collection for a broader study investigating return to smoking following release from smoke-free prisons in Queensland, ${ }^{20}$ reports of teabacco use in Queensland's prisons emerged among several participants. One participant who described making teabacco cigarettes from nicotine lozenges while incarcerated, and who was no longer serving a community corrections order, agreed to meet with researchers in a private location in the community to create samples for analysis. After informed consent procedures, the participant created several samples of teabacco cigarettes. The participant agreed to the filming of his hands while creating the samples so that the process could be replicated in the laboratory, whilst assuring the participant's anonymity. The participant was provided with a supermarket voucher as a reciprocity payment for his time. This study received approval from Griffith University's Human Research Ethics Committee (2015/581).

\section{Production of Teabacco}

All materials provided to the participant were the same brand as those he described using in prison. Based on instructions provided by the participant to the research team prior to the video recording, the provided tea leaves (Bushells Blue Label brand, removed from teabags) had already been rinsed in running cold tap water until the water ran clear, and then left to dry overnight. The participant began by sucking the sugar coating off of the nicotine lozenges (Nicorette Cool Drops $2 \mathrm{mg}$ ). He then crushed the lozenges in a bowl until they resembled powder. The crushed lozenges were then mixed with the rinsed and dried tea leaves at a ratio of three lozenges to one teabag. The participant stirred the mixture thoroughly until the tea leaves were covered in a white residue. The participant then created a cigarette filter using a small piece of cardboard. He assembled the teabacco cigarette by placing the teabacco mixture and a cardboard filter onto a piece of Bible paper, which he then rolled into a cigarette. He used saliva to seal the teabacco cigarette and 
concluded by twisting each end of the cigarette to enclose the contents. In a prison setting, paper would be placed in a microwave to create a flame, which would then be used to ignite the teabacco cigarette. Screenshots from the video of the participant creating the teabacco samples are available as a supplementary file.

\section{Analysis}

A simple linear smoking system ${ }^{21}$ (Figure 1) was designed by authors CM and AW in order to capture the teabacco smoke for analysis. The smoking chamber designed was based on Klus and colleagues, $^{22}$ adaption of the original design by von Neurath et al. ${ }^{23}$ The result was an aluminium chamber (side and rear views shown in Figures 2 and 3 respectively) with a polytetrafluoroethylene (PTFE) cigarette holder (Figure 4). Table 1 describes the components of the smoking system used to capture the teabacco cigarette smoke for analysis.

Adjacent to the smoking chamber was a solvent based trap ${ }^{24}$; consisting of a liquid solvent (methanol or toluene) in a Dreschel bottle or impinger. This allowed the smoke to be bubbled through a liquid and captured by either cooling or chemical interaction with the chosen solvent. As this style of trap is susceptible to breakthrough of high concentration compounds, ${ }^{24}$ the trap was cryogenically cooled ${ }^{24}$ with dry ice in isopropanol $\left(-78^{\circ} \mathrm{C}\right) .^{25}$

In order to simulate a person smoking a cigarette, consideration of variables such as puff frequency (puff duration and inter-puff interval), puff volume, puff duration and puff flow rate ${ }^{26}$ was required. The Massachusetts regime ${ }^{27}$ for smoking was selected, as it was deemed the closest to the human average ${ }^{28}$ (Table 2). A timing and switching system was designed to mimic the preferred smoking cycle. Two timers were interconnected and used to control a solenoid valve (Figure 5). A manual switch was also installed to simulate the quick and short puffs smokers employ until the cigarette is completely lit.

Table 3 describes the materials used to create teabacco samples in the laboratory. Cigarettes were constructed similar in size and concentrations to those created by the participant, with the exception of the rolling method; to ensure consistency when rolling multiple teabacco cigarettes, the Bible paper casing was rolled around a hexagonal Allen key $(4.5 \mathrm{~mm}$ ) before saliva was applied (as adhesive) using a cotton Q-tip swab. The casing was then left to dry, before a section of one end was twisted to enclose the cigarette. The teabacco mixture was then created by mixing crushed nicotine lozenges (Nicorette Cool Drops 2mg) with rinsed tea leaves (Bushells blue label) at a ratio of three lozenges to one teabag. The paper casing was then 
filled with teabacco, with occasional tapping, before the rolled cardboard filter was inserted. The cigarette was then smoked by the linear smoking system. Four cigarettes were smoked per trap, with three replicate traps per solvent.

Gravimetric determination of the total particulate matter (TPM; includes water, nicotine and condensable tar) 'inhaled' by the linear smoking system occurred through use of a second cigarette filter tip located inside the PTFE cigarette holder. During smoking, recorded outcomes included the overall smoke time, number of puffs, and the weight of the second filter both before and after smoking. The difference in weight was used to calculate TPM/puff. A cigarette was considered successfully 'smoked' if a range of 1215 puffs was achieved (as per average use of a commercial cigarette).

Prior to analysis, the liquid captured from each solvent trap was freeze dried to remove solvent. The sample residues were then placed back into solution at a concentration of approximately $3000 \mathrm{mg} / \mathrm{L}$; in either methanol or dichloromethane (substituted for toluene). Analysis of the captured smoke was conducted by gas chromatography coupled with a mass spectrometer (GC-MS); compounds were identified using the National Institute of Standards and Technology (NIST) mass spectral library (Version 2.2, 2014). Retention indexing was used to constrain the search parameters to improve library identification results. Samples were run on a GC-MS with a $240^{\circ} \mathrm{C}$ injection port at an initial temperature of $85^{\circ} \mathrm{C}$, held for two minutes, and the temperature was then ramped at $20^{\circ} \mathrm{C} / \mathrm{min}$ until $180^{\circ} \mathrm{C}$ and then held for a further minute. The oven was then ramped again at $40{ }^{\circ} \mathrm{C} / \mathrm{min}$ and held isothermally at $280^{\circ} \mathrm{C}$ for eight minutes. Carrier gas flow was controlled by linear velocity at $1.10 \mathrm{~mL} / \mathrm{min}$. Mass spectral information was gathered from 40 to $600 \mathrm{~m} / \mathrm{z}$ with single ion monitoring (SIM) channels of 84,133 and $162 \mathrm{~m} / \mathrm{z}$ being used to monitor and quantify the nicotine within the sample.

Elemental composition of the teabacco cigarette materials (shown in Table 3), along with other identified potential materials used, were analysed by inductively coupled plasma optical emission spectroscopy (ICP-OES). Each sample was run in triplicate and involved digestion using concentrated nitric acid and a microwave sample preparation system, before being analysed for the presence of 23 elements, including various toxic heavy metals. Table 4 describes the instruments used for analysis. The analysis was conducted using a Perkin Elmer Optima 8300 ICP-OES which was operated at 1450 watts with flowrates of $10 \mathrm{~L} / \mathrm{min}, 0.3 \mathrm{~L} / \mathrm{min}$ and $0.7 \mathrm{~L} / \mathrm{min}$ for plasma, auxiliary and nebulising gases respectively. Sample flow rate was set at $1.5 \mathrm{~mL} / \mathrm{min}$. 
Tea cigarettes (washed and unwashed), containing only tea and no nicotine lozenges, were analysed by GC-MS and TPM was determined gravimetrically, as a comparison to the teabacco cigarettes; in order to identify components that originated specifically from the lozenges, rather than those from the tea and the bible paper. Winfield Original Blue cigarettes (a common brand available for commercial purchase) were also analysed by GC-MS and ICP-OES as a comparison to teabacco cigarettes.

\section{RESULTS}

\section{Elemental Analysis by ICP-OES}

Elemental compositions of the teabacco cigarette materials (Table 3), along with other identified potential materials used were determined by ICP-OES (Table 5). The 23 elements tested include macro and trace minerals required for healthy function and development, along with toxic heavy metals that can be potentially consumed through dietary intake. Considering that individuals may smoke a pack of 20 cigarettes in one day, the total potential exposure of each element was calculated (Table 6) for a minimum of 20 cigarettes (being the smallest sized 'pack' of commercially-produced cigarettes available).

Results from ICP-OES were compared to recommended daily intakes/recommended dietary allowances and upper intake limits, preferably from the World Health Organization (WHO). These analyses pertain to the potential exposure of a person to the concentrations determined in Table 5. The maximum risk of exposure possible by smoking teabacco cigarettes was considered, compared to guidelines and deemed excessive or not (Table 7).

\section{Gravimetric Determination of Total Particulate Matter}

Total particulate matter (TPM) was collected for each different type of handmade cigarette (teabacco, washed and unwashed tea) by using a separate Ranch cigarette filter tip per cigarette. The average experimental weights of total particulate matter were recorded by collecting 12 data points per trap polarity (equivalent to 24 points per tobacco/teabacco product; see Table 8) and compared to an established maximum limit and literature value for Winfield Original Blue cigarettes.

\section{Identification of Compounds by GC-MS}

The identity of several possible compounds collected by both the methanol and toluene solventbased traps was determined by GC-MS using the NIST mass spectral library (Table 9, Table 10). Figures 6 and 7 show representative GC-MS chromatograms of trap residues captured in methanol and toluene, 
respectively, for the smoking of washed teabacco cigarettes. A number of compounds were identified by GC-MS from the smoke captured in the methanol solvent-based traps from all samples (Table 9). Compounds identified in the teabacco samples (both filtered and unfiltered) include (Z)-9-octadecenamide, 1,6-anhydro- $\beta$-D-glucopyranose, catechol, dianhydromannitol, DL-glucitol, nicotine and octadecanoic acid. In the toluene solvent-based trap (Table 10), the compounds identified in the teabacco samples (both filtered and unfiltered) by GC-MS included 5-methyl-2-(1-methylethyl)-cyclohexanol, dianhydromannitol, diethyl phthalate, nicotine, and octadecanoic acid. Compounds identified in teabacco cigarettes, along with washed and unwashed tea cigarettes, including the likely source and potential toxicity of each are collated for comparison in Table 11.

Nicotine levels in the teabacco cigarette were monitored to determine whether this non-standard form of cigarette could deliver a reasonable level of nicotine, as opposed to the user ingesting the supplied lozenge as intended (2mg nicotine), or smoking commercial cigarettes (reported nicotine levels in Winfield Blue $0.86 \mathrm{mg}^{29}(\operatorname{tar} 9.1 \mathrm{mg})^{29}$ ). Nicotine levels were determined using single ion monitoring GC-MS, and a standard curve was generated in a range from 1 to $250 \mathrm{mg} / \mathrm{L}$ in dichloromethane, with the samples processed against this. Nicotine levels accessible via the smoking process were calculated based on nicotine per gram of smoking product and nicotine per gram of trap residue. Tables 12 and 13 show the resulting nicotine recovered in methanol traps via the smoking process for tobacco and 'teabacco' products (represented graphically in Figures 8 and 9). It was determined that as a function of grams of smoking material, the washed tea product and Winfield Blue cigarette deliverable comparable values $(0.092 \mathrm{mg} / \mathrm{g} v \mathrm{vs} 0.85 \mathrm{mg} / \mathrm{g})$, with the teabacco product delivering significantly less nicotine at $0.014 \mathrm{mg} / \mathrm{g}$ of product. In comparison, the mass of nicotine recovered from the trap residues were determined to be $3.98 \mathrm{mg} / \mathrm{g}$ (Winfield Blue cigarettes), $3.77 \mathrm{mg} / \mathrm{g}$ (washed tea) and $2.00 \mathrm{mg} / \mathrm{g}$ (teabacco). Noted is the mass of the trap residues for Winfield and washed tea, delivering on average $47.6 \mathrm{mg}$ and $31.5 \mathrm{mg}$ of residue, and the teabacco residues yielding $14.7 \mathrm{mg}$ of residue.

\section{DISCUSSION}

Our analyses identified a number of compounds present in teabacco made from nicotine lozenges.

First, when comparing results from inductively coupled plasma-optical emission spectroscopy (ICP-OES) to recommended dietary allowances and upper intake limits, typically from the World Health Organization (WHO), only copper and aluminium were identified in amounts that may be of health concern. $2932.56 \mu \mathrm{g} / \mathrm{g}$ (2.9 mg) of copper was identified in samples of the Gideon's Holy Bible inked pages, which surpasses the 
recommended dietary allowance of copper $(0.9 \mathrm{mg} \text { per day })^{30}$ and has the potential to cause general gastric irritation in sensitive individuals. ${ }^{31}$ Two other Bible paper samples (The Shire of Pine Rivers and New International Version; both inked and non-inked) were found to have between $16208.56 \mu \mathrm{g} / \mathrm{g}(16.2 \mathrm{mg})$ and $27558.84 \mu / \mathrm{g}(27.5 \mathrm{mg})$ of aluminium, surpassing the provisional weekly intake of $2 \mathrm{mg}$ per $\mathrm{kg}^{32}$ of body weight when smoking more than a 'pack-a-day' (>20 cigarettes). A possible link between increased ingestion of aluminium and Alzheimer's disease has been identified, but not established. ${ }^{31,33}$ However, it is important to note that these analyses pertain to the potential exposure of a person to the concentrations determined by ICP-OES for each element, and that full exposure is extremely unlikely, as consumption through inhalation depends on several parameters. ${ }^{34}$

In our comparison of the upper limits of potential elemental exposure (teabacco cigarettes versus traditional tobacco cigarettes), we identified $190 \mu \mathrm{g}(0.19 \mathrm{mg})$ of lead per 20 teabacco cigarettes smoked. While there is currently no universally-accepted allowance for safe lead ingestion, ${ }^{35,36}$ a previous tolerable weekly intake of $25 \mu \mathrm{g}$ per kg body weight was deemed unacceptably high. ${ }^{31,37,38}$ As a result, any individuals smoking a 'pack-a-day' of teabacco each week are at risk of some negative health effects due to potential exposure nearing the withdrawn weekly intake. Potential health effects from lead exposure include headaches and irritability, anaemia, tremors, or paralysis. ${ }^{31,37,38}$ Lead has also been classified as a possible carcinogen to humans. $31,37,38$

Total particulate matter (TPM) varied for each teabacco cigarette, which may be due to the tightness of the rolled filter or the consistency of the tea. In 2001, a maximum limit of $10 \mathrm{mg}$ per cigarette ${ }^{39}$ was established for TPM, but it can vary between 4.9 - $13.2 \mathrm{mg}$ per cigarette. ${ }^{40,41}$ While the Winfield Original Blue cigarettes comply ${ }^{42}$ with this imposed limit, the upper TPM range for a teabacco cigarette is slightly higher than the limit at $10.91 \mathrm{mg}$ per cigarette. Inhaled TPM poses an unknown aspirated risk, which could be detrimental to individuals smoking teabacco cigarettes. General health effects from the deposition of particulate matter in the respiratory system include irritation, inflammation, and decreased lung function. ${ }^{43,44}$ This does not take into account any health effects that could occur from the absorption of constituents contained within the total particulate matter of teabacco cigarettes.

Compounds identified by gas chromatography coupled with a mass spectrometer (GC-MS) in the teabacco samples (both filtered and unfiltered) include (Z)-9-octadecenamide, 1,6-anhydro- $\beta$-Dglucopyranose, 5-methyl-2-(1-methylethyl)-cyclohexanol, catechol, dianhydromannitol, diethyl phthalate, DL-glucitol, nicotine, and octadecanoic acid. None of these compounds are considered toxic to humans, ${ }^{45-51}$ 
with the exception of catechol and nicotine. Catechol is one of the major products from pyrolysis of catechin, ${ }^{52}$ which is present in black tea. ${ }^{53}$ Catechol is considered a tumour promoter, ${ }^{54}$ and has been previously identified in mainstream tobacco smoke. ${ }^{55,56}$ Nicotine is a highly addictive $\mathrm{e}^{57}$ psychoactive substance ${ }^{58}$ present in commercially available tobacco. ${ }^{106}$ Exposure to nicotine promotes lung tumour progression and metastasis, ${ }^{59}$ and development of emphysema. ${ }^{59}$ Octadecanoic acid, also known as stearic acid, ${ }^{50}$ was also identified. Octadecanoic acid is a saturated fatty acid which contributes to the aroma and flavour of black tea, ${ }^{60,61}$ and while inhalation of octadecanoic acid may cause respiratory tract irritation, the compound is not considered toxic. ${ }^{62}$

Review of the nicotine levels in teabacco demonstrated that teabacco is on a similar scale to commercial tobacco with respect to delivery of nicotine. Noted are the high levels of nicotine reported in smoking of unwashed black tea. This is not to be unexpected as levels as high as $1.66 \mu \mathrm{g} / \mathrm{g}$ have been reported by Siegmund and colleagues, in tea varieties. ${ }^{63}$ Large discrepancies between measured and reported values may lie in three areas; the variable nature of the tea product, as described by Siegmund, ${ }^{63}$ the way the nicotine is sampled (i.e. smoking), and the potential signal noise in the SIM signal due to the complex nature of the tea sample.

While a number of potentially harmful compounds were identified in our analyses of teabacco made from nicotine lozenges, our findings show that smoking of this form of teabacco is still less harmful than smoking teabacco made from nicotine patches, ${ }^{17}$ or smoking traditional tobacco cigarettes. However, considering the presence of these potentially harmful compounds, we recommend the implementation of prison-based awareness programs highlighting the potential harmful effects of smoking teabacco, and that the nicotine lozenge be consumed by oral ingestion instead (as per dosage instructions). Nicotine replacement therapies, when used as intended, are designed to give the therapeutic relief achieved from smoking, but without the added detrimental health effects and with significantly lower toxicity. ${ }^{64,65}$ With nicotine lozenges currently being the only smoking cessation support available to people entering Queensland's prisons-a population with one of the highest levels of tobacco use in Australia ${ }^{1,66}$ and of all global prison populations ${ }^{2,8}$ — our findings question the wisdom of automatically removing nicotine lozenges from correctional facilities in response to the creation and use of teabacco, at least until further research directly establishes the health harms resulting from smoking teabacco made from nicotine lozenges.

\section{Limitations}


While this is the first study to analyse the chemical constituents of teabacco made from nicotine lozenges, and as such lays groundwork for future research, this study suffers four main limitations. First, we were limited to a single operational sample of teabacco cigarette, and as such the samples received from the participant and recreated in the laboratory may not be representative of other samples of teabacco created and smoked by prisoners. Second, TPM was determined gravimetrically as a whole, and the composition was not analysed to determine individual constituents. Composition of the TPM would assist with determining the unknown aspiration risk. Third, GC-MS analysis was qualitative not quantitative, and quantitation of the compounds present would assist with determining the overall potential toxicity of the handmade teabacco cigarettes. While the quantitation of nicotine in the unwashed black tea showed a substantial amount of nicotine, further exploration needs to be undertaken due to the complex and variable nature of the tea leading to interference in the sample matrix. Finally, there were four cigarettes per solvent (methanol or toluene) trap, with three traps per cigarette type (teabacco, washed and unwashed tea) analysed by GC-MS for this study. More replicate traps per cigarette sample type would increase the reliability of the compounds identified.

\section{Conclusion}

While our analysis identified a number of compounds present in the smoke produced from teabacco made from nicotine lozenges, the only identified compounds of potential health concern were catechol and nicotine. Quantitation of nicotine across the samples showed that teabacco includes a quantity of nicotine comparable to commercial cigarettes, however more work needs to be done to investigate potential interferences present in our analytical methodologies. Elemental composition determined that copper, aluminium and lead concentrations also raised potential health concerns, with the identified quantities of these three elements being above recommended guidelines for safe ingestion. Inhaled total particulate matter poses limited potential risk to the respiratory system. Overall, the potential of teabacco made from nicotine lozenges to result in health harm is much lower than the risk of harm resulting from smoking teabacco made from nicotine patches, or from smoking traditional tobacco cigarettes, and with nicotine lozenges representing the only form of smoking cessation support to individuals entering smoke-free prisons, we caution against the removal of nicotine lozenges from Queensland's correctional facilities, at least until further research directly establishes the health harms associated with the use of this form of teabacco. 


\section{References}

1. AIHW. National Drug Strategy Household Survey 2016 Key Findings. Canberra, Australia; 2017. Available at: http://www.aihw.gov.au/alcohol-and-other-drugs/data-sources/ndshs-2016/keyfindings/.

2. Baybutt M, Ritter C, Stöver H. Tobacco Use in Prison Settings: A Need for Policy Implementation. Geneva, Switzerland; 2014. Available at: http://www.euro.who.int/_data/assets/pdf_file/0004/249205/Prisons-and-Health,-16-Tobacco-use-inprison-settings-a-need-for-policy.pdf.

3. Binswanger IA, Carson EA, Krueger PM, Mueller SR, Steiner JF, Sabol WJ. Prison tobacco control policies and deaths from smoking in United States prisons: population based retrospective analysis. BMJ 2014;349:1-12. doi:10.1136/bmj.g4542.

Butler TG, Richmond RL, Belcher JM, Wilhelm KA, Wodak AD. Should smoking be banned in prisons? Tob. Control 2007;16(5):291-3. doi:10.1136/tc.2007.021600.

5. Jayes LR, Ratschen E, Murray RL, Dymond-White S, Britton J. Second-hand smoke in four English prisons: An air quality monitoring study. BMC Public Health 2016;16(1):1-8. doi:10.1186/s12889016-2757-y.

6. Naylor B. Smoking in Prisons: Whose Rights? Melbourne, Australia; 2013. Available at: http://rightnow.org.au/opinion-3/smoking-in-prisons/.

7. Collier R. Prison smoking bans: clearing the air. Can. Med. Assoc. J. 2013;185(10):E474. doi:10.1503/cmaj.109-4486.

8. Kennedy SM, Davis SP, Thorne SL. Smoke-Free Policies in U.S. Prisons and Jails the Literature. Nicotine Tob. Res. 2015:629-635. doi:10.1093/ntr/ntu225.

9. Woodall J, Tattersfield A. Perspectives on implementing smoke-free prison policies in England and Wales. Health Promot. Int. 2017;(October):1-8. doi:10.1093/heapro/dax031.

10. Bonita R, Beaglehole R. New Zealand leads the way in banning smoking in prisons. BMJ 2013;346. doi:10.1136/bmj.f3923. 
11. Butler TG, Yap L. Smoking bans in prison: time for a breather? Med. J. Aust. 2015;203(8):313. doi:10.5694/mja15.00688.

12. Dickert J, Williams JM, Reeves R, Gara M, DeBilio L. Decreased Mortality Rates of Inmates With Mental Illness After a Tobacco-Free Prison Policy. Psychiatr. Serv. 2015:1-5. doi:10.1176/appi.ps.201400429.

13. Hefler M, Hopkins R, Thomas DP. Successes and unintended consequences of the Northern Territory's smoke-free prisons policy: results from a process evaluation. Public Heal. Res. Pract. 2016;26(2):1-8. doi:http://dx.doi.org/10.17061/phrp2621619.

14. Collinson L, Wilson N, Edwards R, Thomson G, Thornley S. New Zealand's smokefree prison policy appears to be working well: one year on. J. New Zeal. Med. Assoc. 2012;125(1357):164-168. Available at: https://www.nzma.org.nz/journal/read-the-journal/all-issues/2010-2019/2012/vol-125no-1357/letter-collinson.

15. Independent Monitoring Boards. Annual Report of the Independent Monitoring Board at HMP Cardiff. Cardiff, Wales; 2018. Available at: https://www.imb.org.uk/cardiff-2016-17-annual-reportpublished-today/.

16. Djachenko A, St John W, Mitchell C. Smoking cessation in smoke-free prisons: a grounded theory study. Int. J. Prison. Health 2016;12(4):270-279. doi:10.1108/IJPH-06-2016-0019.

17. Morrissey H, Ball P, Boland M, Hefler M, Thomas DP. Constituents of smoke from cigarettes made from diverted nicotine replacement therapy patches. Drug Alcohol Rev. 2016;35(2):206-211. doi:10.1111/dar.12288.

18. Michael P. Queensland prisoners smoke tea leaves soaked in nicotine after smoking ban. The Courier Mail. http://www.couriermail.com.au/news/queensland/queensland-prisoners-smoke-tea-leavessoaked-in-nicotine-after-smoking-ban/news-story/0c185f2ad2d73875a3588044ea2962c3. Published May 15, 2014.

19. Pearson E. Highly trained dog squad is on the job at Lara prisons. Geelong Advertiser. http://www.geelongadvertiser.com.au/news/geelong/highly-trained-dog-squad-is-on-the-job-at-laraprisons/news-story/f953536ad9c73b23b554b40a13544724. Published June 5, 2016. 
20. Puljević C, de Andrade D, Coomber R, Kinner SA. Relapse to smoking following release from smoke-free correctional facilities in Queensland, Australia. Drug Alcohol Depend. 2018;187:127-133. doi:10.1016/j.drugalcdep.2018.02.028.

21. Physicians for a Smoke Free Canada. How Cigarettes Are Tested For Chemical Content. Vancouver, Canada; 1998. Available at: http://www.smoke-free.ca/factsheets/pdf/cigtestfactsheet.pdf.

22. Klus H, Boenke-Nimphius B, Müller L. Cigarette mainstream smoke: The evolution of methods and devices for generation, exposure and collection. Beitrage zur Tab. Int. Contrib. to Tob. Res. 2016;27(4):137-274. doi:10.1515/cttr-2016-0015.

23. von Neurath G, Ehmke H. An Apparatus for the Determination of Sidestream Smoke / Apparatur zur Untersuchung des Nebenstromrauches. Contrib. to Tob. Res. 1964;2(4):1-5. doi:10.2478/cttr-20130064.

24. Sampson MM, Chambers DM, Pazo DY, Moliere F, Blount BC, Watson CH. Simultaneous analysis of 22 volatile organic compounds in cigarette smoke using gas sampling bags for high-throughput solid-phase microextraction. Anal. Chem. 2014;86(14):7088-7095. doi:10.1021/ac5015518.

25. Roemer E, Schramke H, Weiler H, et al. Mainstream smoke chemistry and in vitro and in vivo toxicity of the reference cigarettes 3R4F and 2R4F. Beitrage zur Tab. Int. Contrib. to Tob. Res. 2012;25(1):316-335. doi:10.2478/cttr-2013-0912.

26. Darrall KG. Smoking machine parameters and cigarette smoke yields. Sci. Total Environ. 1988;74:263-278. doi:10.1016/0048-9697(88)90142-8.

27. Wright C. Standardized methods for the regulation of cigarette-smoke constituents. Trends Anal. Chem. 2015;66:118-127. doi:10.1016/j.trac.2014.11.011.

28. Zacny JP, Stitzer ML. Human Smoking Patterns.; 1996. Available at: http://cancercontrol.cancer.gov/brp/tcrb/monographs/7/m7_11.pdf.

29. Victoria Health. Product Line Council (Nicotine and Tar Content). Melbourne, Australia; 2018. Available at: https://www2.health.vic.gov.au/Api/downloadmedia/\%7B2B981D89-5DC2-4630-93352F8B3EAC1DFE\%7D. 
30. World Health Organization. Copper in Drinking-Water. Geneva, Switzerland; 2004. doi:10.1016/j.kjms.2011.05.002.

31. World Health Organization. Trace Elements in Human Nutrition and Health. Geneva, Switzerland; 1996. Available at: http://www.who.int/nutrition/publications/micronutrients/9241561734/en/.

32. World Health Organization. Aluminium in Drinking-Water. Geneva, Switzerland; 2010. Available at: http://www.who.int/iris/handle/10665/75362.

33. World Health Organization. Aluminium in Drinking-Water. Geneva, Switzerland; 2010. Available at: http://www.who.int/water_sanitation_health/water-quality/guidelines/chemicals/aluminium.pdf?ua=1.

34. Geiger A, Cooper J. Overview of Airborne Metals Regulations, Exposure Limits, Health Effects, and Contemporary Research.; 2010. doi:10.1212/01.CON.0000480843.89012.5b.

35. World Health Organization. Exposure to Lead: A Major Public Health Concern. Geneva, Switzerland; 2010. doi:10.1016/j.ecoenv.2011.12.007.

36. World Health Organization. Lead in Drinking-Water. Geneva, Switzerland; 2011. doi:10.1155/2013/959637.

37. World Health Organization. Exposure to Lead: A Major Public Health Concern. Geneva, Switzerland; 2010. Available at: http://www.who.int/ipcs/features/lead..pdf?ua=1.

38. World Health Organization. Lead in Drinking-Water. Geneva, Switzerland; 2011. Available at: http://www.who.int/water_sanitation_health/dwq/chemicals/lead.pdf.

39. Greenhalgh E., Scollo MM. Regulation to Disclose or Reduce Harm from Tobacco Products. Melbourne, Australia; 2018. Available at: http://www.tobaccoinaustralia.org.au/chapter-18-harmreduction/18-2-regulation.

40. Eldridge A, Betson TR, Gama MV, McAdam K. Variation in tobacco and mainstream smoke toxicant yields from selected commercial cigarette products. Regul. Toxicol. Pharmacol. 2015;71(3):409-427. doi:10.1016/j.yrtph.2015.01.006.

41. Wright C. Standardized methods for the regulation of cigarette-smoke constituents. Trends Anal. Chem. 2015;66:118-127. doi:10.1016/j.trac.2014.11.011. 
42. Victoria Health. Tar and Nicotine Content of Various Brand Name Cigarettes. Melbourne, Australia; 2018. Available at: www2.health.vic.gov.au/Api/downloadmedia/\%7B2B981D89-5DC2-4630-93352F8B3EAC1DFE\%7D.

43. Bay Area Air Quality Management District. Health Effects of Particulate Matter. Spare Air 2018:21116. doi:10.1177/074823379901500803.

44. U.S. Environmental Protection Agency. Health and Environmental Effects of Particulate Matter $(P M)$.; 2016. Available at: https://www.epa.gov/pm-pollution/health-and-environmental-effectsparticulate-matter-pm.

45. Brown J. (Z)-9-Octadecenamide. Information on Hazardous Chemicals and Occupational Diseases. 2013:1-3. Available at: https://hazmap.nlm.nih.gov/category-details?id=7758\&table=copytblagents. Accessed March 11, 2018.

46. Hutter H-P, Hohenblum P, Scharf S, Weiss S, Wallner P. Levoglucosan in urine as marker of PAH exposure. Biomonitoring 2015;2(1):16-18. doi:10.1515/bimo-2015-0002.

47. National Center for Biotechnology Information. Levomenthol. PubChem 2018:1-56. Available at: https://pubchem.ncbi.nlm.nih.gov/compound/_-_-menthol\#section=Top. Accessed February 1, 2018.

48. Wiggins LF. Anhydrides of the Pentitols and Hexitols. In: ; 1950:191-228. doi:10.1016/S00965332(08)60339-2.

49. Australian Government Department of Health. Diethyl Phthalate (DEP). Canberra, Australia; 2013. Available at: https://www.nicnas.gov.au/chemical-information/factsheets/chemical-name/diethylphthalate-dep.

50. National Center for Biotechnology Information. Stearic Acid.; 2017. Available at: https://pubchem.ncbi.nlm.nih.gov/compound/stearic_acid\#section=Top.

51. Gao F, Gee DL, Hulan PM, Zhuang S, Burke WJ. Patents Nicotine lozenge. 2016:1-12. Available at: https://patents.google.com/patent/US20160354360.

52. Ben H. Pyrolysis of Biomass to Bio-Oils. Atlanta, Georgia; 2014. Available at: https://www.worldscientific.com/doi/pdf/10.1142/9789814513289_0008. 
53. Wang Y, Yang X, Li K, et al. Simultaneous determination of theanine, gallic acid, purine alkaloids, catechins, and theaflavins in black tea using HPLC. Int. J. Food Sci. Technol. 2010;45(6):1263-1269. doi:10.1111/j.1365-2621.2010.02266.x.

54. Gopalakrishna R, Chen ZH, Gundimeda U. Tobacco smoke tumor promoters, catechol and hydroquinone, induce oxidative regulation of protein kinase $\mathrm{C}$ and influence invasion and metastasis of lung carcinoma cells. Proc. Natl. Acad. Sci. U. S. A. 1994;91(25):12233-7. doi:10.1073/pnas.91.25.12233.

55. Vaughan C, Stanfill SB, Polzin GM, Ashley DL, Watson CH. Automated determination of seven phenolic compounds in mainstream tobacco smoke. Nicotine Tob. Res. 2008;10(7):1261-8. doi:10.1080/14622200802123146.

56. Hecht S, Carmella S, Mori H, Hoffman D. A Study of Tobacco Carcinogenesis. XX. Role of Catechol as a Major Cocarcinogen in the Weakly Acidic Fraction of Smoke Condensate. J. Natl. Cancer Inst. 1981;66(1):163-169. doi:10.1093/jnci/66.1.163.

57. Mishra A, Chaturvedi P, Datta S, Sinukumar S, Joshi P, Garg A. Harmful effects of nicotine. Indian J. Med. Paediatr. Oncol. 2015;36(1):24. doi:10.4103/0971-5851.151771.

58. Cancer Council Victoria. Psychoactive Effects of Nicotine. Melbourne, Australia; 2017. Available at: http://www.tobaccoinaustralia.org.au/chapter-6-addiction/6-3-psychoactive-effects-of-nicotine\#x 1.

59. Chaturvedi P, Mishra A, Datta S, Sinukumar S, Joshi P, Garg A. Harmful effects of nicotine. Indian J. Med. Paediatr. Oncol. 2015;36(1):24. doi:10.4103/0971-5851.151771.

60. Zheng XQ, Li QS, Xiang LP, Liang YR. Recent advances in volatiles of teas. Molecules 2016;21(3):1-12. doi:10.3390/molecules21030338.

61. Ravichandran R, Parthiban R. Lipid occurrence, distribution and degradation to flavour volatiles during tea processing. Food Chem. 2000;68(1):7-13. doi:10.1016/S0308-8146(99)00143-0.

62. ChemWatch Review. Pyrogallol.; 2018. Available at: https://jr.chemwatch.net/chemwatch.web/home.

63. Siegmund B, Leitner E, Pfannhauser W. Determination of the nicotine content of various edible nightshades (Solanaceae) and their products and estimation of the associated dietary nicotine intake. 
J. Agric. Food Chem. 1999;47(8):3113-3120. doi:10.1021/jf990089w.

64. Stratton K, Shetty P, Wallace R, Bondurant S. Clearing the Smoke: Assessing the Science Base for Tobacco Harm Reduction. Washington, D.C.: National Academies Press; 2001. Available at: http://www.nap.edu/catalog/10029.

65. Shiffman S, Fant R V, Buchhalter AR, Gitchell JG, Henningfield JE. Nicotine delivery systems. Expert Opin. Drug Deliv. 2005;2(3):563-577. doi:10.1517/17425247.2.3.563.

66. AIHW. The Health of Australia's Prisoners 2015, Cat. No. PHE 207. Canberra, Australia; 2015. Available at: http://www.aihw.gov.au/publication-detail/?id=60129553527.

67. World Health Organization. Standard Operating Procedure for Intense Smoking of Cigarettes. Geneva, Switzerland; 2012. Available at: http://apps.who.int/iris/bitstream/10665/75261/1/9789241503891_eng.pdf.

68. Zacny JP, Stitzer ML. Human Smoking Patterns.; 1996. Available at: https://cancercontrol.cancer.gov/brp/tcrb/monographs/7/m7_11.pdf.

69. World Health Organization. Sodium Intake for Adults and Children. Geneva, Switzerland; 2012. Available at: http://www.who.int/nutrition/publications/guidelines/sodium_intake_printversion.pdf.

70. World Health Organization. Potassium Intake for Adults and Children. Geneva, Switzerland; 2012. Available at: http://apps.who.int/iris/bitstream/10665/77986/1/9789241504829_eng.pdf?ua=1\&ua=1.

71. World Health Organization. Vitamin and Mineral Requirements in Human Nutrition. Geneva, Switzerland; 1998. Available at: http://apps.who.int/iris/bitstream/10665/42716/1/9241546123.pdf.

72. Institute of Medicine (US) Standing Committee on the Scientific Evaluation of Dietary Reference Intakes. Dietary Reference Intakes for Calcium, Phosphorous, Magnesium, Vitamin D, and Fluoride. Washington, D.C.: National Academy Press; 2001. doi:10.1111/j.1753-4887.1997.tb01621.x.

73. Jones DP, Park Y, Gletsu-Miller N, et al. Dietary sulfur amino acid effects on fasting plasma cysteine/cystine redox potential in humans. Nutrition 2011;27(2):199-205. doi:10.1016/j.nut.2010.01.014.

74. Institute of Medicine (US) Standing Committee on the Scientific Evaluation of Dietary Reference 
Intakes. Dietary Reference Intakes for Vitamin A, Vitamin K, Arsenic, Boron, Chromium, Copper, Iodine, Iron, Manganese, Molybdenum, Nickel, Silicon, Vanadium, and Zinc.; 2001. Available at: http://www.nap.edu/catalog/10026.

75. United Nations Environment Program. Zinc. Geneva, Switzerland; 2001. Available at: http://www.inchem.org/documents/ehc/ehc/ehc221.htm.

76. World Health Organization. Copper in Drinking-Water. Geneva, Switzerland; 2004. Available at: http://www.who.int/water_sanitation_health/dwq/chemicals/copper.pdf.

77. Jugdaohsingh R. Silicon and bone health. J. Nutr. Health Aging 2007;11(2):99-110. Available at: http://www.ncbi.nlm.nih.gov/pubmed/17435952\%5Cnhttp://www.pubmedcentral.nih.gov/articlerende r.fcgi?artid=PMC2658806.

78. World Health Organization Joint FAO/WHO Expert Committee on Food Additives. Evaluation of certain food additives and contaminants. WHO Tech. Rep. Ser. 2011;(966):55-70. doi:10.1021/jf60163a014.

79. World Health Organization. Hydrogen Sulfide in Drinking-Water. Geneva, Switzerland; 2003. Available at: http://www.who.int/water_sanitation_health/dwq/chemicals/tinsum.pdf.

80. World Health Organization. Nickel in Drinking-Water. Geneva, Switzerland; 2005. Available at: http://www.who.int/water_sanitation_health/gdwqrevision/nickel2005.pdf.

81. Kim JH, Gibb HJ, Howe PD. Cobalt and Inorganic Cobalt Compounds. World Heal. Organ. 2006:193. Available at: http://www.who.int/ipcs/publications/cicad/cicad70.pdf.

82. World Health Organization. Silver in Drinking-Water. Geneva, Switzerland; 1996. Available at: http://www.who.int/water_sanitation_health/dwq/chemicals/silver.pdf.

83. European Food Safety Panel on Food Additives and Nutrient Sources Added to Food. Scientific Opinion on the re-evaluation of gold (E 175) as a food additive. EFSA J. 2016;14(1):4362. doi:10.2903/j.efsa.2016.4362.

84. Sloof W, Cleven RFM., Janus JA, van der Poel P. Integrated Criteria Document Chromium. Bilthoven, Netherlands; 1990. Available at: 
http://www.rivm.nl/bibliotheek/rapporten/710401002.html.

85. World Health Organization. Arsenic in Drinking-Water. Geneva, Switzerland; 2004. Available at: http://www.who.int/water_sanitation_health/dwq/chemicals/arsenic.pdf.

86. World Health Organization. Cadmium in Drinking-Water. Geneva, Switzerland; 2011. Available at: http://www.who.int/water_sanitation_health/water-quality/guidelines/chemicals/cadmium.pdf?ua=1.

87. World Health Organization. Exposure to Mercury: A Major Public Health Concern. Geneva, Switzerland; 2006. Available at: http://www.who.int/phe/news/Mercury-flyer.pdf.

88. World Health Organization. Chemical Fact Sheets. Geneva, Switzerland; 2010. Available at: http://www.who.int/water_sanitation_health/dwq/gdwq0506_12.pdf?ua=1.

89. National Center for Biotechnology Information. Levoglucosan.; 2018. Available at: https://pubchem.ncbi.nlm.nih.gov/compound/Leucoglucosan\#section=Top.

90. Simoneit BRT, Schauer JJ, Nolte CG, et al. Levoglucosan, a tracer for cellulose in biomass burning and atmospheric particles. Atmos. Environ. 1999;33(2):173-182. doi:10.1016/S1352-2310(98)001459.

91. Nimlos MR, Evans RJ. Levoglucosan Pyrolysis. Fuel Chem. Div. Prepr. 2002;47(1):393.

92. Hutter H-P, Hohenblum P, Scharf S, Weiss S, Wallner P. Levoglucosan in urine as marker of PAH exposure. Biomonitoring 2015;2(1):16-18. doi:10.1515/bimo-2015-0002.

93. Moshammer H, Weiss S, Neuberger M. Woodsmoke marker levoglucosan: Kinetics in a selfexperiment. Int. J. Occup. Med. Environ. Health 2012;25(2):122-125. doi:10.2478/S13382-012-00239.

94. Ben H. Pyrolysis of Biomass to Bio-Oils. Atlanta, Georgia; 2014. Available at: https://www.worldscientific.com/doi/abs/10.1142/9789814513289_0008.

95. Gopalakrishna R, Chen ZH, Gundimeda U. Tobacco smoke tumor promoters, catechol and hydroquinone, induce oxidative regulation of protein kinase $\mathrm{C}$ and influence invasion and metastasis of lung carcinoma cells. Proc. Natl. Acad. Sci. U. S. A. 1994;91(25):12233-7. doi:10.1073/pnas.91.25.12233. 
96. Wiggins LF. Anhydrides of the Pentitols and Hexitols. Adv. Carbohydr. Chem. 1950;5:191-228. doi:10.1016/S0096-5332(08)60339-2.

97. Sowden J. Ethers, Anhydro Sugars, Unsaturated Derivatives. In: Pigman W, ed. The Carbohydrates. Chemistry, Biochemistry, Physiology.Vol 80.; 1962:367-405. doi:10.1021/ja01543a074.

98. U.S. Government Publishing Office. Plasticizers.; 2018. Available at: https://www.ecfr.gov/cgi$\mathrm{bin} /$ retrieveECFR $\mathrm{gp}=1 \& \mathrm{SID}=78 \mathrm{a} 0 \mathrm{ffdde} 9 \mathrm{bd} 0574 \mathrm{cbc} 92 \mathrm{a} 3 \mathrm{ceece} 811 \mathrm{f} \& \mathrm{ty}=\mathrm{HTML} \& \mathrm{~h}=\mathrm{L} \& \mathrm{mc}=$ true $\& \mathrm{r}=$ SECTION\&n=se21.3.181_127.

99. Australian Government Department of Health and Ageing. Diethyl Phthalate. Canberra, Australia; 2008. Available at: https://www.nicnas.gov.au/chemical-information/otherassessments/reports/phthalates-hazard-assessments.

100. National Center for Biotechnology Information. Sorbitol.; 2018. Available at: https://pubchem.ncbi.nlm.nih.gov/compound/D-Sorbitol\#section=Top.

101. Ravichandran R, Parthiban R. Lipid occurrence, distribution and degradation to flavour volatiles during tea processing. Food Chem. 2000;68(1):7-13. doi:10.1016/S0308-8146(99)00143-0.

102. ScienceLab. Material Safety Data Sheet Stearic acid. 2005:4-8. Available at: http://www.sciencelab.com/msds.php?msdsId=9927609.

103. U.S. Department of Health and Human Services. Testing Status of Triacetin M000026.; 2018. Available at: https://ntp.niehs.nih.gov/testing/status/agents/ts-m000026.html.

104. Taniguchi H, Hibi T. Cigarette filter material and cigarette filter. 2005:1-22. Available at: https://patents.google.com/patent/EP1856991A1/en.

105. Touey GP, Kiefer JE. Bonding plasticizers for cigarette filters of cellulose acetate fibers. 2018;(1):17. Available at: https://patents.google.com/patent/US3393684.

106. Blauch JL, Tarka SM. HPLC Determination of Caffeine and Theobromine in Coffee, Tea, and Instant Hot Cocoa Mixes. J. Food Sci. 1983;48(3):745-747. doi:10.1111/j.1365-2621.1983.tb14888.x.

107. Idowu A, Rilwan O, Abdulganiyu O. Three Brands of Chinese Green Tea Confer Immunity and Attenuate Susceptibility to Malaria Infection on a Long Term. J. Nat. Sci. Res. 2017;7(12):49-66. 
Available at: http://iiste.org/Journals/index.php/JNSR/article/download/37562/38642.

108. Zhou JS, Lv SD, Lian M, Wang C, Meng QX. Comparison of the volatile compounds among different production regions of green tea using simultaneous distillation extraction coupled with gas chromatography-mass spectrometry. Adv. J. Food Sci. Technol. 2015;7(8):607-613. doi:10.19026/ajfst.7.1367.

109. ChemWatch Review. 2,3-Dihydrobenzofuran.; 2018. Available at: https://jr.chemwatch.net/chemwatch.web/home.

110. ChemWatch Review. 3-Methoxycatechol.; 2018. Available at: https://jr.chemwatch.net/chemwatch.web/home.

111. Kuo P-C, Lai Y-Y, Chen Y-J, Yang W-H, Tzen JT. Changes in volatile compounds upon aging and drying in oolong tea production. J. Sci. Food Agric. 2011;91(2):293-301. doi:10.1002/jsfa.4184.

112. Sakasegawa M, Yatagai M. Composition of pyrolyzate from Japanese green tea. J. Wood Sci. 2005;51(1):73-76. doi:10.1007/s10086-003-0613-z.

113. Kibet JK, Khachatryan L, Dellinger B. Molecular products from the thermal degradation of glutamic acid. J. Agric. Food Chem. 2013;61(32):7696-7704. doi:10.1021/jf401846t.

114. Krishnamurthy K, Venkitasubramaniam T, Giri K. Circular Paper Chromatographic Analysis of the Amino Acids of Tea and Coffee Infusions. Curr. Sci. 1952;21(5). Available at: http://www.currentscience.ac.in/Downloads/article_id_021_05_0133_0133_0.pdf.

115. ScienceLab. Material Safety Data Sheet Succinimide MSDS.; 2013. Available at: http://www.sciencelab.com/msds.php?msdsId=9925115.

116. Australian Government Department of Health. Ingredients in Winfield Varieties. Canberra, Australia; 2013. Available at: http://www.health.gov.au/internet/publications/publishing.nsf/Content/batatobacco-ingredients-2012 section-a winfield-varieties. 
Table 1. Components of the smoking system used to capture the teabacco cigarette smoke for analysis

\section{Equipment}

Smoking chamber and cigarette

Solvent based trap

Timer and switch system

\section{Use}

Holds the cigarette during smoking Collects the cigarette smoke for analysis Controls the flow of smoke through the system to mimic the puffing cycle

Pulls the cigarette smoke through the system at a constant rate

This article is protected by copyright. All rights reserved. 
Table 2. Comparison of various smoking regimes published in literature.

\begin{tabular}{cccc}
\hline Smoking Regime & Puff Volume & Puff Duration & Inter-puff Interval \\
\hline ISO Standard $^{67}$ & $35 \mathrm{~mL}$ & $2 \mathrm{sec}$ & $60 \mathrm{sec}$ \\
\hline Massachusetts $^{41}$ & $45 \mathrm{~mL}$ & $2 \mathrm{sec}$ & $30 \mathrm{sec}$ \\
\hline Human Average $^{68}$ & $>35 \mathrm{~mL}$ & $1.8 \mathrm{sec}$ & $34 \mathrm{sec}$ \\
\hline
\end{tabular}

This article is protected by copyright. All rights reserved. 
Table 3. Materials used to create the teabacco cigarette samples.

\begin{tabular}{cccc}
\hline Material & Brand & Use & Quantity \\
\hline Inked Bible Paper & God's Word & Cigarette paper & $\sim 36 \mathrm{~mm} \mathrm{x} \mathrm{80} \mathrm{mm}$ \\
\hline Cardboard & Bushells Blue Label (box) & Makeshift filter or 'roach' & $\sim 20 \mathrm{~mm} \mathrm{x} \mathrm{25} \mathrm{mm}$ \\
\hline 2 mg Nicotine Lozenge & Nicorette Cool Drops & In teabacco & 3 lozenges/1 teabag \\
\hline Black Tea (Washed) & Bushells Blue Label & In teabacco & 3 lozenges/1 teabag \\
\hline
\end{tabular}

This article is protected by copyright. All rights reserved. 
Table 4. Instruments used for analysis.

\begin{tabular}{ll}
\multicolumn{1}{c}{ Instrument } & \multicolumn{1}{c}{ Use } \\
\hline Vacuum Freeze Dryer Lab-1 Series & Freeze dry smoke samples to remove solvent \\
\hline $\begin{array}{l}\text { Shimadzu GC-MS TQ8040 } \\
\text { Gas Chromatography Mass Spectrometry }\end{array}$ & $\begin{array}{l}\text { Separates individual components in the smoke sample } \\
\text { and identifies components using a mass spectral library }\end{array}$ \\
\hline $\begin{array}{l}\text { Perkin Elmer Titan MPS Microwave Sample } \\
\text { Preparation System }\end{array}$ & $\begin{array}{l}\text { Digests the raw materials used in teabacco cigarettes for } \\
\text { elemental analysis }\end{array}$ \\
\hline $\begin{array}{l}\text { Perkin Elmer Optima 8300 ICP-OES } \\
\text { Inductively Coupled Plasma Optical Emission Spectroscopy }\end{array}$ & $\begin{array}{l}\text { Determines the elemental composition in the digested } \\
\text { raw materials }\end{array}$ \\
\hline
\end{tabular}

This article is protected by copyright. All rights reserved. 
Table 5. Average elemental concentration $(\mu \mathrm{g} / \mathrm{g})$ determined by ICP-OES from the raw materials.

\begin{tabular}{|c|c|c|c|c|c|c|c|c|c|c|c|c|}
\hline & \multicolumn{6}{|c|}{$\begin{array}{l}\text { Gideon's } \\
\text { Holy Bible }\end{array}$} & \multicolumn{6}{|c|}{ God's Word } \\
\hline & Inked & STD & $\%$ error & No Ink & STD & $\%$ error & Inked & STD & $\%$ error & No Ink & STD & $\%$ error \\
\hline $\mathbf{N a}$ & 311.74 & 73.88 & $23.70 \%$ & 400.75 & 10.73 & $2.68 \%$ & 607.97 & 24.28 & $3.99 \%$ & 622.71 & 31.54 & $5.07 \%$ \\
\hline $\mathbf{K}$ & $\mathrm{BDL}$ & $\mathrm{BDL}$ & $\mathrm{BDL}$ & BDL & $\mathrm{BDL}$ & $\mathrm{BDL}$ & $\mathrm{BDL}$ & $\mathrm{BDL}$ & $\mathrm{BDL}$ & 46.92 & 12.51 & $26.67 \%$ \\
\hline Mg & 3625.95 & 869.43 & $23.98 \%$ & 2718.68 & 609.76 & $22.43 \%$ & 281.13 & 7.72 & $2.75 \%$ & 272.23 & 6.40 & $2.35 \%$ \\
\hline $\mathrm{Ca}$ & 1332.28 & 130.11 & $9.77 \%$ & 2096.06 & 365.23 & $17.42 \%$ & 15952.24 & 1279.42 & $8.02 \%$ & 16012.11 & 237.23 & $1.48 \%$ \\
\hline Mn & BDL & BDL & BDL & $\mathrm{BDL}$ & BDL & $\mathrm{BDL}$ & $\mathrm{BDL}$ & BDL & BDL & $\mathrm{BDL}$ & $\mathrm{BDL}$ & $\mathrm{BDL}$ \\
\hline Zn & $\mathrm{BDL}$ & $\mathrm{BDL}$ & BDL & 22.00 & 14.84 & $67.44 \%$ & 63.80 & 62.76 & $98.36 \%$ & 149.60 & 158.81 & $106.16 \%$ \\
\hline $\mathbf{S i}$ & 192.88 & 85.85 & $44.51 \%$ & 185.48 & 153.79 & $82.92 \%$ & $\mathrm{BDL}$ & $\mathrm{BDL}$ & $\mathrm{BDL}$ & $\mathrm{BDL}$ & BDL & $\mathrm{BDL}$ \\
\hline Al & 2983.78 & 583.05 & $19.54 \%$ & 4157.25 & 1403.80 & $33.77 \%$ & 1176.15 & 43.87 & $3.73 \%$ & 1047.33 & 44.99 & $4.30 \%$ \\
\hline $\mathrm{Cu}$ & $2932.56^{a}$ & 5784.49 & $197.25 \%$ & 10.56 & 4.92 & $46.60 \%$ & 2.05 & 0.95 & $46.19 \%$ & 1.10 & 0.70 & $64.18 \%$ \\
\hline Sn & BDL & $\mathrm{BDL}$ & BDL & BDL & BDL & BDL & BDL & $\mathrm{BDL}$ & BDL & BDL & BDL & $\mathrm{BDL}$ \\
\hline $\mathbf{N i}$ & 2.06 & 0.20 & $9.82 \%$ & 2.27 & 0.09 & $4.15 \%$ & 1.37 & 0.05 & $4.00 \%$ & 1.31 & 0.06 & $4.77 \%$ \\
\hline Co & 0.50 & 0.33 & $65.82 \%$ & 0.59 & 0.10 & $17.93 \%$ & 0.65 & 0.02 & $3.57 \%$ & 0.68 & 0.05 & $6.89 \%$ \\
\hline $\mathrm{Cr}$ & 1.27 & 0.11 & $8.77 \%$ & 1.78 & 0.12 & $6.62 \%$ & 1.65 & 0.18 & $10.92 \%$ & 1.49 & 0.07 & $4.72 \%$ \\
\hline $\mathbf{P b}$ & 8.66 & 8.03 & $92.73 \%$ & 5.08 & 0.36 & $7.06 \%$ & 9.22 & 0.23 & $2.52 \%$ & 8.90 & 0.21 & $2.39 \%$ \\
\hline As & BDL & $\mathrm{BDL}$ & BDL & $\mathrm{BDL}$ & BDL & BDL & BDL & BDL & $\mathrm{BDL}$ & BDL & BDL & $\mathrm{BDL}$ \\
\hline Cd & BDL & $\mathrm{BDL}$ & $\mathrm{BDL}$ & BDL & $\mathrm{BDL}$ & BDL & BDL & BDL & $\mathrm{BDL}$ & BDL & $\mathrm{BDL}$ & $\mathrm{BDL}$ \\
\hline Hg & 11.80 & 2.16 & $18.30 \%$ & 12.21 & 0.45 & $3.69 \%$ & $\mathrm{BDL}$ & BDL & BDL & $\mathrm{BDL}$ & BDL & $\mathrm{BDL}$ \\
\hline Se & 1.74 & 0.16 & $9.03 \%$ & BDL & BDL & BDL & 4.08 & 0.30 & $7.28 \%$ & BDL & BDL & $\mathrm{BDL}$ \\
\hline $\mathrm{Fe}$ & 86.91 & 18.73 & $21.55 \%$ & 76.85 & 5.99 & $7.79 \%$ & 106.21 & 10.50 & $9.89 \%$ & 98.97 & 27.38 & $27.66 \%$ \\
\hline Ag & 3.15 & 4.12 & $130.74 \%$ & 1.25 & 0.14 & $11.55 \%$ & 2.39 & 0.07 & $3.07 \%$ & 2.43 & 0.03 & $1.07 \%$ \\
\hline $\mathbf{S}$ & BDL & BDL & BDL & $\mathrm{BDL}$ & $\mathrm{BDL}$ & BDL & 543.40 & 46.81 & $8.61 \%$ & 576.26 & 115.10 & $19.97 \%$ \\
\hline $\mathbf{P}$ & 34.00 & 6.59 & $19.38 \%$ & 27.36 & 6.83 & $24.95 \%$ & 48.89 & 5.73 & $11.72 \%$ & 37.45 & 3.27 & $8.72 \%$ \\
\hline Au & 29.72 & 1.73 & $5.83 \%$ & 30.57 & 0.38 & $1.23 \%$ & 1.69 & 0.25 & $14.63 \%$ & 1.82 & 0.06 & $3.56 \%$ \\
\hline
\end{tabular}

This article is protected by copyright. All rights reserved. 


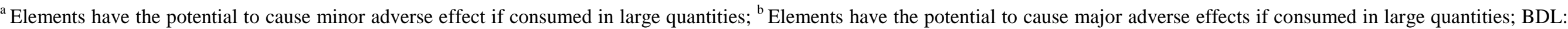
below detectable limits. 
Table 5 cont. Average elemental concentration $(\mu \mathrm{g} / \mathrm{g})$ determined by ICP-OES from the raw materials.

\begin{tabular}{|c|c|c|c|c|c|c|c|c|c|c|c|c|}
\hline & \multicolumn{6}{|c|}{$\begin{array}{c}\text { Holy Bible New } \\
\text { International Version }\end{array}$} & \multicolumn{6}{|c|}{$\begin{array}{c}\text { Holy Bible Share } \\
\text { of Pine Rivers }\end{array}$} \\
\hline & Inked & STD & $\%$ error & No Ink & STD & $\%$ error & Inked & STD & $\%$ error & No Ink & STD & $\%$ error \\
\hline $\mathbf{N a}$ & 341.86 & 17.72 & $5.18 \%$ & 400.91 & 43.05 & $10.74 \%$ & 1796.42 & 91.27 & $5.08 \%$ & 1804.32 & 28.01 & $1.55 \%$ \\
\hline $\mathbf{K}$ & 1117.99 & 252.06 & $22.55 \%$ & 1135.85 & 72.15 & $6.35 \%$ & 627.71 & 28.89 & $4.60 \%$ & 617.04 & 23.99 & $3.89 \%$ \\
\hline Mg & 178.36 & 38.01 & $21.31 \%$ & 161.19 & 2.50 & $1.55 \%$ & 584.10 & 6.83 & $1.17 \%$ & 602.67 & 10.61 & $1.76 \%$ \\
\hline $\mathbf{C a}$ & 97.16 & 10.50 & $10.81 \%$ & 113.72 & 22.71 & $19.97 \%$ & 26788.37 & 879.02 & $3.28 \%$ & 26203.91 & 460.00 & $1.76 \%$ \\
\hline Mn & BDL & BDL & BDL & $\mathrm{BDL}$ & BDL & $\mathrm{BDL}$ & $\mathrm{BDL}$ & BDL & $\mathrm{BDL}$ & $\mathrm{BDL}$ & $\mathrm{BDL}$ & BDL \\
\hline $\mathbf{Z n}$ & 14.14 & 1.99 & $14.10 \%$ & 18.44 & 7.62 & $41.35 \%$ & 4.59 & 0.19 & $4.19 \%$ & $\mathrm{BDL}$ & $\mathrm{BDL}$ & $\mathrm{BDL}$ \\
\hline Si & BDL & BDL & BDL & BDL & BDL & BDL & BDL & $\mathrm{BDL}$ & BDL & $\mathrm{BDL}$ & BDL & BDL \\
\hline Al & $16208.56^{\mathrm{a}}$ & 4138.12 & $25.53 \%$ & $16741.69^{a}$ & 760.15 & $4.54 \%$ & $27558.84^{a}$ & 349.90 & $1.27 \%$ & $27395.70^{a}$ & 450.41 & $1.64 \%$ \\
\hline $\mathrm{Cu}$ & 5.46 & 1.31 & $24.04 \%$ & 8.33 & 4.21 & $50.61 \%$ & 2.26 & 0.37 & $16.19 \%$ & 1.55 & 0.11 & $7.38 \%$ \\
\hline Sn & $\mathrm{BDL}$ & $\mathrm{BDL}$ & BDL & BDL & $\mathrm{BDL}$ & BDL & $\mathrm{BDL}$ & BDL & BDL & BDL & $\mathrm{BDL}$ & BDL \\
\hline $\mathbf{N i}$ & 0.97 & 0.17 & $17.88 \%$ & 1.29 & 0.35 & $27.31 \%$ & 1.16 & 0.17 & $14.84 \%$ & 1.19 & 0.09 & $7.42 \%$ \\
\hline Co & 0.56 & 0.12 & $21.70 \%$ & 0.58 & 0.05 & $8.18 \%$ & 0.63 & 0.06 & $8.85 \%$ & 0.55 & 0.07 & $12.36 \%$ \\
\hline $\mathrm{Cr}$ & 6.20 & 1.17 & $18.95 \%$ & 6.35 & 1.69 & $26.67 \%$ & 4.26 & 0.21 & $4.89 \%$ & 4.09 & 0.09 & $2.25 \%$ \\
\hline $\mathbf{P b}$ & BDL & BDL & BDL & $\mathrm{BDL}$ & BDL & BDL & 5.15 & 1.25 & $24.31 \%$ & 4.97 & 0.52 & $10.39 \%$ \\
\hline As & BDL & BDL & $\mathrm{BDL}$ & BDL & $\mathrm{BDL}$ & $\mathrm{BDL}$ & $\mathrm{BDL}$ & BDL & BDL & BDL & $\mathrm{BDL}$ & BDL \\
\hline Cd & BDL & $\mathrm{BDL}$ & BDL & BDL & BDL & BDL & BDL & BDL & BDL & $\mathrm{BDL}$ & $\mathrm{BDL}$ & BDL \\
\hline Hg & BDL & BDL & BDL & $\mathrm{BDL}$ & BDL & $\mathrm{BDL}$ & BDL & BDL & BDL & BDL & BDL & BDL \\
\hline $\mathrm{Se}$ & 4.23 & 0.93 & $22.04 \%$ & 4.65 & 0.32 & $6.90 \%$ & 6.27 & 0.87 & $13.93 \%$ & 6.09 & 0.24 & $4.01 \%$ \\
\hline $\mathrm{Fe}$ & 344.82 & 76.59 & $22.21 \%$ & 679.15 & 632.20 & $93.09 \%$ & 236.25 & 4.21 & $1.78 \%$ & 230.90 & 6.95 & $3.01 \%$ \\
\hline Ag & 1.97 & 0.04 & $2.18 \%$ & 2.09 & 0.33 & $15.60 \%$ & 2.19 & 0.22 & $10.13 \%$ & 2.15 & 0.14 & $6.71 \%$ \\
\hline $\mathbf{S}$ & 247.01 & 17.20 & $6.96 \%$ & 260.82 & 19.97 & $7.66 \%$ & 111.92 & 0.96 & $0.86 \%$ & 105.75 & 7.74 & $7.32 \%$ \\
\hline $\mathbf{P}$ & 61.06 & 12.87 & $21.07 \%$ & 59.03 & 1.57 & $2.67 \%$ & 135.27 & 1.92 & $1.42 \%$ & 129.73 & 2.49 & $1.92 \%$ \\
\hline Au & $\mathrm{BDL}$ & $\mathrm{BDL}$ & $\mathrm{BDL}$ & $\mathrm{BDL}$ & BDL & BDL & 1.15 & 0.12 & $10.54 \%$ & 2.16 & 1.41 & $65.39 \%$ \\
\hline
\end{tabular}

This article is protected by copyright. All rights reserved. 


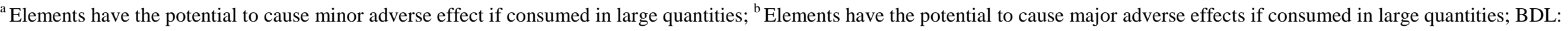
below detectable limits.

Table 5 cont. Average elemental concentration $(\mu \mathrm{g} / \mathrm{g})$ determined by ICP-OES from the raw materials.

\begin{tabular}{|c|c|c|c|c|c|c|c|c|c|c|c|c|}
\hline \multirow[b]{2}{*}{$\mu g / g$} & \multicolumn{6}{|c|}{$\begin{array}{c}\text { New Testament } \\
\text { Psalms and Proverbs }\end{array}$} & \multicolumn{6}{|c|}{$\begin{array}{c}\text { New World Translation } \\
\text { of the Holy Scriptures }\end{array}$} \\
\hline & Inked & STD & $\%$ error & No Ink & STD & $\%$ error & Inked & STD & $\%$ error & No Ink & STD & $\%$ error \\
\hline $\mathbf{N a}$ & 2103.88 & 208.87 & $9.93 \%$ & 1855.80 & 248.69 & $13.40 \%$ & 1016.64 & 5.33 & $0.52 \%$ & 955.98 & 56.31 & $5.89 \%$ \\
\hline $\mathbf{K}$ & BDL & BDL & BDL & BDL & BDL & BDL & 429.59 & 32.16 & $7.49 \%$ & 377.12 & 64.57 & $17.12 \%$ \\
\hline Ig & 715.94 & 95.22 & $13.30 \%$ & 639.58 & 9.46 & $1.48 \%$ & 208.49 & 15.56 & $7.46 \%$ & 284.35 & 53.43 & $18.79 \%$ \\
\hline $\mathbf{C a}$ & 97935.07 & 2676.03 & $2.73 \%$ & 93979.35 & 1786.13 & $1.90 \%$ & 26013.60 & 1017.07 & $3.91 \%$ & 23612.08 & 583.90 & $2.47 \%$ \\
\hline Mn & BDL & BDL & BDL & BDL & BDL & BDL & BDL & BDL & BDL & BDL & BDL & BDL \\
\hline $\mathbf{Z n}$ & BDL & BDL & $\mathrm{BDL}$ & BDL & BDL & BDL & BDL & BDL & BDL & 15.14 & 6.76 & $44.62 \%$ \\
\hline Si & 41.45 & 10.44 & $25.18 \%$ & 44.13 & 20.29 & $45.99 \%$ & 173.80 & 70.26 & $40.43 \%$ & 280.41 & 67.68 & $24.13 \%$ \\
\hline Al & 265.73 & 29.19 & $10.99 \%$ & 618.00 & 641.20 & $103.75 \%$ & 9597.30 & 1845.77 & $19.23 \%$ & 10093.33 & 2366.28 & $23.44 \%$ \\
\hline $\mathrm{Cu}$ & 36.00 & 7.07 & $19.65 \%$ & 1.59 & 0.58 & $36.70 \%$ & 5.30 & 0.94 & $17.68 \%$ & 3.77 & 0.91 & $24.06 \%$ \\
\hline Sn & BDL & BDL & BDL & BDL & BDL & BDL & BDL & BDL & BDL & BDL & BDL & BDL \\
\hline $\mathbf{N i}$ & 0.95 & 0.09 & $9.42 \%$ & 0.96 & 0.09 & $8.91 \%$ & 1.34 & 0.11 & $8.51 \%$ & 1.62 & 0.24 & $14.66 \%$ \\
\hline Co & 1.00 & 0.26 & $25.66 \%$ & 0.58 & 0.05 & $7.84 \%$ & 0.69 & 0.16 & $23.88 \%$ & 0.92 & 0.15 & $16.59 \%$ \\
\hline $\mathrm{Cr}$ & 1.81 & 0.05 & $2.83 \%$ & 3.94 & 4.66 & $118.29 \%$ & 3.97 & 0.21 & $5.41 \%$ & 3.95 & 0.25 & $6.45 \%$ \\
\hline $\mathbf{P b}$ & 6.12 & 0.63 & $10.25 \%$ & 6.18 & 0.24 & $3.94 \%$ & 7.08 & 0.33 & $4.72 \%$ & 7.83 & 1.07 & $13.71 \%$ \\
\hline $\mathbf{S}$ & BDL & BDL & BDL & BDL & BDL & BDL & BDL & BDL & BDL & BDL & BDL & BDL \\
\hline Cd & BDL & BDL & BDL & BDL & BDL & $\mathrm{BDL}$ & BDL & BDL & $\mathrm{BDL}$ & BDL & BDL & BDL \\
\hline Hg & BDL & BDL & BDL & BDL & BDL & BDL & BDL & BDL & BDL & BDL & BDL & BDL \\
\hline $\mathrm{Se}$ & BDL & BDL & BDL & BDL & BDL & BDL & BDL & BDL & BDL & BDL & BDL & BDL \\
\hline $\mathbf{F e}$ & 67.02 & 10.73 & $16.01 \%$ & 79.61 & 21.15 & $26.57 \%$ & 250.67 & 28.60 & $11.41 \%$ & 229.21 & 24.70 & $10.78 \%$ \\
\hline Ag & 2.01 & 0.07 & $3.35 \%$ & 1.97 & 0.02 & $1.16 \%$ & 2.07 & 0.07 & $3.31 \%$ & 2.51 & 0.12 & $4.64 \%$ \\
\hline $\mathbf{S}$ & 76.75 & 19.55 & $25.47 \%$ & BDL & BDL & BDL & 408.16 & 8.76 & $2.15 \%$ & 360.71 & 13.67 & $3.79 \%$ \\
\hline $\mathbf{P}$ & 42.43 & 3.08 & $7.25 \%$ & 46.46 & 0.53 & $1.14 \%$ & 109.25 & 0.85 & $0.78 \%$ & 95.95 & 1.95 & $2.03 \%$ \\
\hline
\end{tabular}

This article is protected by copyright. All rights reserved. 
Au

1.94

0.00

$0.04 \%$

BDL

BDL

BDL

3.39

1.48

$43.66 \% \quad$ BDL

BDL

BDL

below detectable limits.

Table 5 cont. Average elemental concentration $(\mu \mathrm{g} / \mathrm{g})$ determined by ICP-OES from the raw materials.

\begin{tabular}{|c|c|c|c|c|c|c|c|c|c|c|c|c|}
\hline - & $\begin{array}{r}\text { Winfi } \\
\text { Blut }\end{array}$ & $\begin{array}{l}\text { Id Origin } \\
\text { Cigarette }\end{array}$ & & $\begin{array}{r}\text { Nicor } \\
\mathrm{D} \\
\end{array}$ & $\begin{array}{l}\text { tte Coo } \\
\text { ops }\end{array}$ & & & & $\begin{array}{r}\text { Bushells } \\
\text { Bla }\end{array}$ & $\begin{array}{l}\text { Blue Label } \\
\text { Tea }\end{array}$ & & \\
\hline$\mu \mathrm{g} / \mathrm{g}$ & (Filter Cut Off) & STD & $\%$ error & Nicotine Lozenge & STD & $\%$ error & Washed & STD & $\%$ error & Unwashed & STD & $\%$ error \\
\hline $\mathbf{N a}$ & 502.45 & 49.35 & $9.82 \%$ & 4800.30 & 90.25 & $1.88 \%$ & 294.70 & 2.39 & $0.81 \%$ & BDL & BDL & BDL \\
\hline $\mathbf{K}$ & 25602.75 & 1021.21 & $3.99 \%$ & 1239.42 & 34.39 & $2.77 \%$ & BDL & $\mathrm{BDL}$ & BDL & 15870.31 & 180.43 & $1.14 \%$ \\
\hline Mg & 5176.49 & 200.16 & $3.87 \%$ & 940.42 & 14.33 & $1.52 \%$ & 1625.71 & 23.42 & $1.44 \%$ & 1885.64 & 25.99 & $1.38 \%$ \\
\hline $\mathbf{C a}$ & 2580.72 & 79.02 & $3.06 \%$ & 75.62 & 0.95 & $1.26 \%$ & 1450.41 & 13.24 & $0.91 \%$ & 480.48 & 11.26 & $2.34 \%$ \\
\hline Mn & 126.47 & 12.02 & $9.50 \%$ & $\mathrm{BDL}$ & $\mathrm{BDL}$ & $\mathrm{BDL}$ & 250.29 & 4.35 & $1.74 \%$ & 1148.51 & 21.53 & $1.87 \%$ \\
\hline $\mathbf{Z n}$ & 9.10 & 2.96 & $32.53 \%$ & BDL & BDL & $\mathrm{BDL}$ & 69.34 & 34.89 & $50.32 \%$ & BDL & BDL & $\mathrm{BDL}$ \\
\hline $\mathbf{S i}$ & 46.32 & 18.08 & $39.02 \%$ & BDL & BDL & BDL & BDL & BDL & BDL & $\mathrm{BDL}$ & BDL & $\mathrm{BDL}$ \\
\hline Al & 419.11 & 32.19 & $7.68 \%$ & 53.27 & 1.34 & $2.51 \%$ & 1150.54 & 120.70 & $10.49 \%$ & 1267.43 & 15.90 & $1.25 \%$ \\
\hline $\mathbf{C u}$ & 9.86 & 0.31 & $3.13 \%$ & 0.28 & 0.14 & $49.69 \%$ & 178.96 & 3.02 & $1.69 \%$ & 14.01 & 0.36 & $2.58 \%$ \\
\hline Sn & BDL & BDL & BDL & BDL & BDL & BDL & BDL & BDL & BDL & BDL & BDL & BDL \\
\hline $\mathbf{N i}$ & 2.57 & 0.08 & $3.14 \%$ & 0.89 & 0.02 & $2.06 \%$ & 6.22 & 0.07 & $1.19 \%$ & 6.76 & 0.40 & $5.93 \%$ \\
\hline Co & 0.21 & 0.06 & $28.91 \%$ & 0.58 & 0.02 & $3.88 \%$ & BDL & BDL & BDL & BDL & BDL & BDL \\
\hline $\mathrm{Cr}$ & 1.20 & 0.05 & $4.53 \%$ & 1.68 & 0.06 & $3.59 \%$ & 6.30 & 0.27 & $4.33 \%$ & 7.65 & 0.84 & $10.98 \%$ \\
\hline $\mathbf{P b}$ & 3.19 & 0.00 & $0.08 \%$ & 5.26 & 0.22 & $4.25 \%$ & 7.65 & 0.12 & $1.62 \%$ & 2.93 & 0.75 & $25.44 \%$ \\
\hline As & $\mathrm{BDL}$ & BDL & BDL & BDL & BDL & BDL & BDL & BDL & BDL & BDL & BDL & BDL \\
\hline Cd & 0.51 & 0.10 & $19.91 \%$ & BDL & BDL & BDL & BDL & BDL & $\mathrm{BDL}$ & BDL & $\mathrm{BDL}$ & BDL \\
\hline Hg & $9.01^{b}$ & 1.58 & $17.55 \%$ & BDL & $\mathrm{BDL}$ & BDL & 10.45 & 0.17 & $1.66 \%$ & 7.32 & 0.36 & $4.95 \%$ \\
\hline $\mathrm{Se}$ & BDL & BDL & BDL & 3.19 & 0.18 & $5.52 \%$ & BDL & BDL & BDL & BDL & BDL & BDL \\
\hline $\mathbf{F e}$ & 235.86 & 11.08 & $4.70 \%$ & 11.86 & 0.40 & $3.39 \%$ & 198.59 & 5.19 & $2.61 \%$ & 206.92 & 9.06 & $4.38 \%$ \\
\hline Ag & 0.70 & 0.03 & $3.91 \%$ & 2.16 & 0.08 & $3.88 \%$ & 1.08 & 0.05 & $4.20 \%$ & 1.16 & 0.05 & $4.17 \%$ \\
\hline $\mathbf{S}$ & 3602.50 & 133.32 & $3.70 \%$ & 364.20 & 6.77 & $1.86 \%$ & 2352.38 & 19.25 & $0.82 \%$ & 2644.22 & 24.42 & $0.92 \%$ \\
\hline
\end{tabular}

This article is protected by copyright. All rights reserved. 


\begin{tabular}{|c|c|c|c|c|c|c|c|c|c|c|}
\hline 1795.80 & 96.56 & $\begin{array}{l}5.38 \% \\
5.40 \%\end{array}$ & 20.80 & $\begin{array}{l}0.84 \\
\mathrm{RDI}\end{array}$ & $4.02 \%$ & 1823.18 & 27.11 & $1.49 \%$ & 2359.13 & 46.22 \\
\hline
\end{tabular}

${ }^{a}$ Elements have the potential to cause minor adverse effect if consumed in large quantities; ${ }^{b}$ Elements have the potential to cause major adverse effects if consumed in large quantities; BDL: below detectable limits.

Table 5 cont. Average elemental concentration $(\mu \mathrm{g} / \mathrm{g})$ determined by ICP-OES from the raw materials.

\begin{tabular}{ccccccc} 
& \multicolumn{5}{c}{$\begin{array}{c}\text { Nerada Organics } \\
\text { Green Tea }\end{array}$} \\
\cline { 2 - 7 } $\boldsymbol{\mu g} / \mathbf{g}$ & Washed & STD & \% error & Unwashed & STD & \% error \\
$\mathbf{N a}$ & 353.68 & 15.20 & $4.30 \%$ & BDL & BDL & BDL \\
$\mathbf{K}$ & BDL & BDL & BDL & 10769.17 & 1626.92 & $15.11 \%$ \\
$\mathbf{M g}$ & 1376.04 & 30.20 & $2.19 \%$ & 1314.83 & 177.46 & $13.50 \%$ \\
$\mathbf{C a}$ & 1459.22 & 48.45 & $3.32 \%$ & 572.76 & 92.89 & $16.22 \%$ \\
$\mathbf{M n}$ & 156.97 & 5.44 & $3.47 \%$ & 451.01 & 75.02 & $16.63 \%$ \\
$\mathbf{Z n}$ & 27.56 & 13.63 & $49.44 \%$ & 9.08 & 2.18 & $23.95 \%$ \\
$\mathbf{S i}$ & BDL & BDL & BDL & BDL & BDL & BDL \\
$\mathbf{A l}$ & 1379.93 & 30.13 & $2.18 \%$ & 1336.11 & 259.50 & $19.42 \%$ \\
$\mathbf{C u}$ & 76.82 & 2.05 & $2.67 \%$ & 12.24 & 0.89 & $7.24 \%$ \\
$\mathbf{S n}$ & BDL & BDL & BDL & BDL & BDL & BDL \\
$\mathbf{N i}$ & 2.59 & 0.21 & $8.09 \%$ & 6.51 & 0.89 & $13.72 \%$ \\
$\mathbf{C o}$ & BDL & BDL & BDL & BDL & BDL & BDL \\
$\mathbf{C r}$ & 0.76 & 0.10 & $13.48 \%$ & 0.92 & 0.08 & $8.76 \%$ \\
$\mathbf{P b}$ & 5.15 & 0.46 & $8.87 \%$ & 2.08 & 0.21 & $10.27 \%$ \\
$\mathbf{A s}$ & BDL & BDL & BDL & BDL & BDL & BDL \\
$\mathbf{C d}$ & BDL & BDL & BDL & BDL & BDL & BDL \\
$\mathbf{H g}$ & 10.57 & 0.92 & $8.70 \%$ & 9.48 & 0.39 & $4.16 \%$ \\
$\mathbf{S e}$ & BDL & BDL & BDL & BDL & BDL & BDL \\
$\mathbf{F e}$ & 121.84 & 4.92 & $4.04 \%$ & 103.74 & 13.45 & $12.97 \%$ \\
$\mathbf{A g}$ & 1.06 & 0.05 & $4.61 \%$ & 1.08 & 0.05 & $4.47 \%$
\end{tabular}




$\begin{array}{ccccccc}\mathbf{S} & 2336.39 & 72.52 & 3.10 \% & 2243.04 & 320.58 & 14.29 \% \\ \mathbf{P} & 1564.42 & 41.75 & 2.67 \% & 1566.53 & 193.33 & 12.34 \% \\ \mathbf{A u} & 26.40 & 0.41 & 1.54 \% & 26.44 & 0.07 & 0.26 \%\end{array}$

${ }^{a}$ Elements have the potential to cause minor adverse effect if consumed in large quantities; ${ }^{\mathrm{b}}$ Elements have the potential to cause major adverse effects if consumed in large quantities; BDL: below detectable limits. 
Table 6. Comparison between teabacco and commercial cigarettes by examination of the upper limits for each element.

\begin{tabular}{|c|c|c|}
\hline mg/20 Cigarettes & Teabacco Cigarettes & Winfield Cigarettes \\
\hline $\mathbf{N a}$ & 105.69 & 10.04 \\
\hline $\mathbf{K}$ & 26.69 & 484.56 \\
\hline Mg & 32.05 & 97.85 \\
\hline $\mathbf{C a}$ & 43.08 & 48.41 \\
\hline Mn & 1.78 & 2.52 \\
\hline Zn & 0.96 & 0.22 \\
\hline Si & $\mathrm{BDL}$ & 1.17 \\
\hline Al & 12.24 & 8.21 \\
\hline $\mathbf{C u}$ & 1.29 & 0.19 \\
\hline Sn & $\mathrm{BDL}$ & $\mathrm{BDL}$ \\
\hline $\mathbf{N i}$ & 0.07 & 0.05 \\
\hline Co & 0.01 & 0.00 \\
\hline $\mathrm{Cr}$ & 0.09 & 0.02 \\
\hline $\mathbf{P b}$ & $0.19^{b}$ & 0.06 \\
\hline As & $\mathrm{BDL}$ & $\overline{\mathrm{BDL}}$ \\
\hline Cd & $\mathrm{BDL}$ & 0.01 \\
\hline $\mathrm{Hg}$ & 0.07 & $0.19^{b}$ \\
\hline Se & 0.08 & $\mathrm{BDL}$ \\
\hline $\mathbf{F e}$ & 1.89 & 4.49 \\
\hline Ag & 0.06 & 0.01 \\
\hline $\mathbf{S}$ & 25.41 & 67.99 \\
\hline $\mathbf{P}$ & 13.47 & 34.44 \\
\hline $\mathbf{A u}$ & 0.19 & 0.42 \\
\hline
\end{tabular}

${ }^{a}$ Elements have the potential to cause minor adverse effect if consumed in large quantities; ${ }^{b}$ Elements have the potential to cause major adverse effects if consumed in large quantities; BDL: below detectable limits. 
Table 7. Elemental guidelines for recommended daily consumption and upper limits, used to determine if smoking teabacco cigarettes results in excessive, potentially harmful exposure.

\begin{tabular}{|c|c|c|c|}
\hline $\begin{array}{c}\text { Macro } \\
\text { Minerals }\end{array}$ & $\begin{array}{c}\text { Dietary } \\
\text { Allowance }\end{array}$ & $\begin{array}{l}\text { Upper } \\
\text { Limit }\end{array}$ & $\begin{array}{c}\text { Excessive Exposure } \\
\text { from Teabacco }\end{array}$ \\
\hline Sodium & $2.0 \mathrm{~g} / \mathrm{day}^{69}$ & - & No \\
\hline Potassium & 3.5 g/day $^{70}$ & - & No \\
\hline Magnesium & $190-260 \mathrm{mg} / \mathrm{day}^{71}$ & - & No \\
\hline Calcium & $1{\mathrm{~g} / \mathrm{day}^{71}}^{71}$ & - & No \\
\hline Phosphorous & $700 \mathrm{mg} / \mathrm{day}^{72}$ & - & No \\
\hline Sulphur & $4.4 \mathrm{mg} / \mathrm{kg}^{73}$ & - & No \\
\hline $\begin{array}{c}\text { Trace } \\
\text { Minerals }\end{array}$ & $\begin{array}{c}\text { Dietary } \\
\text { Allowance }\end{array}$ & $\begin{array}{l}\text { Upper } \\
\text { Limit }\end{array}$ & $\begin{array}{c}\text { Excessive Exposure } \\
\text { from Teabacco }\end{array}$ \\
\hline Manganese & $1.8-2.3 \mathrm{mg} / \mathrm{day}^{74}$ & $11 \mathrm{mg} / \mathrm{day}^{74}$ & No \\
\hline Zinc & $1.0-1.4 \mathrm{mg} / \mathrm{day}^{71}$ & $8.8-14.4 \mathrm{mg} /$ day $^{75}$ & $\mathrm{No}$ \\
\hline Copper & $0.9 \mathrm{mg} / \mathrm{day}^{76}$ & $10 \mathrm{mg} / \mathrm{day}^{76}$ & Yes \\
\hline Selenium & $20-200 \mu \mathrm{g} /$ day $^{3 \Gamma}$ & - & No \\
\hline Iron & $8 \mathrm{mg} / \mathrm{day}^{74}$ & - & No \\
\hline Other Elements & $\begin{array}{c}\text { Dietary Intake } \\
\text { and Ranges }\end{array}$ & $\begin{array}{l}\text { Upper } \\
\text { Limit }\end{array}$ & $\begin{array}{c}\text { Excessive Exposure } \\
\text { from Teabacco }\end{array}$ \\
\hline Silicon & $20-204 \mathrm{mg} /$ day $^{77}$ & - & No \\
\hline Aluminium & $2 \mathrm{mg} / \mathrm{kg} /$ week $^{78}$ & - & Yes \\
\hline Tin & $\begin{array}{c}14 \mathrm{mg} / \mathrm{kg} / \text { week }^{31,79} \\
\left(2 \mathrm{mg} / \mathrm{kg} / \text { day }^{79}\right)\end{array}$ & - & No \\
\hline Nickel & $12 \mu \mathrm{g} / \mathrm{kg} /$ day $^{80}$ & - & No \\
\hline Cobalt & $5-40 \mu \mathrm{g} /$ day $^{81}$ & - & No \\
\hline Silver & $7-88 \mu \mathrm{g} / \mathrm{day}^{82}$ & - & No \\
\hline Gold & $<0.01-1.32 \mu \mathrm{g} / \mathrm{kg}^{83}$ & - & No \\
\hline $\begin{array}{c}\text { Toxic Heavy } \\
\text { Metals } \\
\end{array}$ & $\begin{array}{c}\text { Tolerable Intake and } \\
\text { Dietary Ranges }\end{array}$ & $\begin{array}{l}\text { Upper } \\
\text { Limit }\end{array}$ & $\begin{array}{c}\text { Excessive Exposure } \\
\text { from Teabacco }\end{array}$ \\
\hline Chromium & $50-200 \mu \mathrm{g} / \mathrm{day}^{84}$ & $>250 \mu \mathrm{g} / \mathrm{day}^{31}$ & No \\
\hline Lead & $2-64 \mu \mathrm{g} / \mathrm{kg}$ per week ${ }^{31}$ & $\begin{array}{c}\text { Previously 25 } \\
\mu \mathrm{g} / \mathrm{kg} / \text { week }^{31,37,38}\end{array}$ & Maybe \\
\hline Arsenic & $15 \mu \mathrm{g} / \mathrm{kg} /$ week $^{85}$ & - & No \\
\hline Cadmium & $25 \mu \mathrm{g} / \mathrm{kg} / \mathrm{month}^{86}$ & - & No \\
\hline Mercury & - & $2 \mu \mathrm{g} / \mathrm{kg} / \mathrm{day}^{87,88}$ & No \\
\hline
\end{tabular}


Table 8. Average experimental values for the gravimetric determination of total particulate matter (TPM).

\begin{tabular}{ccccc} 
& $\begin{array}{c}\text { Average } \\
\text { TPM }(\mathrm{mg})\end{array}$ & $\begin{array}{c}\text { TPM Range } \\
(\mathrm{mg})\end{array}$ & $\begin{array}{c}\text { Average } \\
\text { Puffs }\end{array}$ & $\begin{array}{c}\text { TPM/Puff } \\
(\mathrm{mg} / \mathrm{Puff})\end{array}$ \\
\hline Teabacco Cigarette & $6.56 \pm 4.35$ & $0.90-15.70$ & $13.92 \pm 1.91$ & $0.46 \pm 0.30$ \\
\hline Washed Tea Cigarette & $13.08 \pm 6.99$ & $0.50-21.90$ & $15.04 \pm 0.20$ & $0.87 \pm 0.47$ \\
\hline Unwashed Tea Cigarette & $9.32 \pm 2.33$ & $5.60-13.10$ & $15.00 \pm 0.00$ & $0.62 \pm 0.16$ \\
\hline
\end{tabular}

This article is protected by copyright. All rights reserved. 
Table 9. Compounds identified by GC-MS, from the smoke captured in the methanol solventbased trap.

\begin{tabular}{|c|c|c|c|c|c|}
\hline Compound Identified & $\begin{array}{l}\text { Teabacco } \\
\text { (Filtered) }\end{array}$ & $\begin{array}{l}\text { Teabacco } \\
\text { (Unfiltered) }\end{array}$ & $\begin{array}{c}\text { Tea } \\
\text { (Washed) }\end{array}$ & $\begin{array}{c}\text { Tea } \\
\text { (Unwashed) }\end{array}$ & $\begin{array}{c}\text { Winfield } \\
\text { Original } \\
\text { Blue }\end{array}$ \\
\hline (Z)-9-Octadecenamide & Identified & & & & \\
\hline 1,2,3-Benzenetriol & & & Identified & Identified & \\
\hline 1,2-Diacetate Glycerol & & & Identified & Identified & Identified \\
\hline $\begin{array}{l}\text { 1,6-Anhydro-ß-D- } \\
\text { Glucopyranose }\end{array}$ & Identified & Identified & Identified & Identified & Identified \\
\hline 2,3-Dihydro-Benzofuran & & & & Identified & \\
\hline 3-Pyridinol & & & & Identified & \\
\hline Caffeine & & & Identified & & \\
\hline Catechol & & Identified & & Identified & Identified \\
\hline Dianhydromannitol & Identified & Identified & & & \\
\hline DL-Glucitol & & Identified & & & \\
\hline Hydroquinone & & & & Identified & Identified \\
\hline Nicotine & Identified & Identified & & & Identified \\
\hline Octadecanoic Acid & Identified & & & & \\
\hline Succinimide & & & & Identified & \\
\hline Triacetin & & & Identified & Identified & Identified \\
\hline
\end{tabular}


Table 10. Compounds identified by GC-MS, from the smoke captured in the toluene solventbased trap.

\begin{tabular}{|c|c|c|c|c|c|}
\hline Compound Identified & $\begin{array}{l}\text { Teabacco } \\
\text { (Filtered) }\end{array}$ & $\begin{array}{c}\text { Teabacco } \\
\text { (Unfiltered) }\end{array}$ & $\begin{array}{c}\text { Tea } \\
\text { (Washed) }\end{array}$ & $\begin{array}{c}\text { Tea } \\
\text { (Unwashed) }\end{array}$ & $\begin{array}{c}\text { Winfield } \\
\text { Original } \\
\text { Blue }\end{array}$ \\
\hline 1,2,3-Benzenetriol & & & & Identified & \\
\hline 1,2-Diacetate Glycerol & & & & Identified & Identified \\
\hline $\begin{array}{l}\text { 1,6-Anhydro- } \beta \text {-D- } \\
\text { Glucopyranose }\end{array}$ & & & Identified & & \\
\hline $\begin{array}{l}\text { 3-Methoxy-1,2- } \\
\text { Benzenediol }\end{array}$ & & & & Identified & \\
\hline 3-Pyridinol & & & & Identified & \\
\hline $\begin{array}{l}\text { 5-Methyl-2-(1- } \\
\text { Methylethyl)- } \\
\text { Cyclohexanol }\end{array}$ & Identified & & & & \\
\hline Caffeine & & & & Identified & \\
\hline Catechol & & & & Identified & \\
\hline Dianhydromannitol & Identified & & & & \\
\hline Diethyl Phthalate & Identified & & & & \\
\hline Hydroquinone & & & & Identified & \\
\hline Nicotine & Identified & & & & Identified \\
\hline Octadecanoic Acid & Identified & & & & \\
\hline Theobromine & & & & Identified & \\
\hline Triacetin & & & & Identified & \\
\hline
\end{tabular}


Table 11. Compounds identified for each type of handmade cigarette, by GC-MS, the source of the compound and potential toxicity.

\begin{tabular}{|c|c|c|}
\hline $\begin{array}{c}\text { Compounds } \\
\text { Teabacco Cigarettes }\end{array}$ & Source & Potential Toxicity \\
\hline (Z)-9-Octadecenamide & $\begin{array}{l}\text { Nicotine lozenge - dispersion aid in } \\
\text { surface coatings. }\end{array}$ & Not toxic \\
\hline $\begin{array}{l}\text { 1,6-Anhydro- } \beta \text {-D- } \\
\text { Glucopyranose }\end{array}$ & $\begin{array}{l}\text { Bible paper and tea - pyrolysis of } \\
\text { carbohydrates, such as starch }{ }^{89} \text { and } \\
\text { cellulose }^{90,91}\end{array}$ & $\begin{array}{l}\text { Not toxic, }{ }^{92} \text { excreted in } \\
\text { urine }^{93}\end{array}$ \\
\hline $\begin{array}{l}\text { 5-Methyl-2-(1- } \\
\text { Methylethyl)- } \\
\text { Cyclohexanol } \\
\end{array}$ & $\begin{array}{l}\text { Nicotine lozenge - produced from } \\
\text { peppermint, and is used as mint } \\
\text { flavouring plastic. }\end{array}$ & Not toxic \\
\hline Catechol & $\begin{array}{c}\text { Tea - pyrolysis of catechin, }{ }^{94} \text { present } \\
\text { in black tea }{ }^{53}\end{array}$ & $\begin{array}{l}\text { Tumour promoter, } \\
\text { increases cell } \\
\text { metastasis }\end{array}$ \\
\hline Dianhydromannitol & $\begin{array}{l}\text { Nicotine lozenge - non-toxic }{ }^{96} \\
\text { plasticiser }^{97} \text { which is dispersed } \\
\text { throughout the soluble-fibre matrix } \\
\text { and coating }\end{array}$ & Not toxic \\
\hline Diethyl Phthalate & $\begin{array}{l}\text { Highly volatile }{ }^{49} \text { plasticiser }^{98} \text { used in } \\
\text { pharmaceutical products }\end{array}$ & $\begin{array}{l}\text { Not toxic, excreted in } \\
\text { urine }\end{array}$ \\
\hline DL-Glucitol & $\begin{array}{c}\text { Nicotine lozenge - (sorbitol) }{ }^{100} \text { sugar } \\
\text { alcohol }^{51,100} \text { used as a sweetener and } \\
\text { bulking agent }\end{array}$ & Not toxic \\
\hline Nicotine & Nicotine lozenge & $\begin{array}{l}\text { Role in development of } \\
\text { emphysema, lung tumor } \\
\text { progression and } \\
\text { metastisis }\end{array}$ \\
\hline Octadecanoic Acid & $\begin{array}{l}\text { Tea - stearic acid }{ }^{50} \text { saturated fatty } \\
\text { acid, contributes to aroma and } \\
\text { flavour of black tea } \\
60,101\end{array}$ & $\begin{array}{l}\text { Inhalation may cause } \\
\text { respiratory irritation, } \\
\text { compound is not toxic }^{102}\end{array}$ \\
\hline $\begin{array}{c}\text { Compounds Washed Tea } \\
\text { Cigarettes }\end{array}$ & Source & Potential Toxicity \\
\hline 1,2,3-Benzenetriol & $\begin{array}{l}\text { Tea - pyrolysis product }{ }^{62} \text { from } \\
\text { Gallic acid (from tannins) }\end{array}$ & $\begin{array}{l}\text { Inhalation may cause } \\
\text { respiratory irritation, } \\
\text { genetic mutations }\end{array}$ \\
\hline 1,2-Diacetate Glycerol & $\begin{array}{l}\text { Cellulose acetate cigarette } \\
\text { filters }{ }^{103-105} \text { (TPM analysis) }\end{array}$ & - \\
\hline $\begin{array}{l}\text { 1,6-Anhydro- } \beta \text {-D- } \\
\text { Glucopyranose }\end{array}$ & $\begin{array}{c}\text { Bible paper and tea - pyrolysis of } \\
\text { carbohydrates, such as starch }{ }^{89} \text { and } \\
\text { cellulose }^{90,91}\end{array}$ & $\begin{array}{c}\text { Not toxic, }{ }^{92} \underset{\text { urine }}{\operatorname{excreted}} \\
\text { in }\end{array}$ \\
\hline Caffeine & $\mathrm{Tea}^{106}$ & Not toxic \\
\hline
\end{tabular}




\begin{tabular}{|c|c|c|}
\hline Triacetin & $\begin{array}{l}\text { Cellulose acetate cigarette } \\
\text { filters }{ }^{103-105} \text { (TPM analysis) }\end{array}$ & - \\
\hline $\begin{array}{c}\text { Compounds Unwashed } \\
\text { Tea Cigarettes }\end{array}$ & Source & Potential Toxicity \\
\hline 1,2,3-Benzenetriol & $\begin{array}{l}\text { Tea - pyrolysis product }{ }^{62} \text { from } \\
\text { Gallic acid (from tannins) }\end{array}$ & $\begin{array}{l}\text { Inhalation may cause } \\
\text { respiratory irritation, } \\
\text { genetic mutations }\end{array}$ \\
\hline 1,2-Diacetate Glycerol & $\begin{array}{l}\text { Cellulose acetate cigarette } \\
\text { filters }{ }^{103-105} \text { (TPM analysis) }\end{array}$ & - \\
\hline $\begin{array}{l}\text { 1,6-Anhydro- } \beta \text {-D- } \\
\text { Glucopyranose }\end{array}$ & $\begin{array}{l}\text { Bible paper and tea - pyrolysis of } \\
\text { carbohydrates, such as starch }{ }^{89} \text { and } \\
\text { cellulose }\end{array}$ & $\begin{array}{l}\text { Not toxic, }{ }^{92} \text { excreted in } \\
\text { urine }^{93}\end{array}$ \\
\hline 2,3-Dihydrobenzofuran & $\begin{array}{l}\text { Tea - found in Camellia sinensis } \\
\text { plant }^{107,108}\end{array}$ & Not toxic ${ }^{109}$ \\
\hline $\begin{array}{l}\text { 3-Methoxy-1,2- } \\
\text { Benzenediol }\end{array}$ & $\begin{array}{c}\text { Tea - found in Camellia sinensis } \\
\text { plant }\end{array}$ & $\begin{array}{l}\text { Inhalation may cause } \\
\text { respiratory irritation }\end{array}$ \\
\hline 3-Pyridinol & $\begin{array}{l}\text { Tea - found in Camellia sinensis } \\
\text { plant }^{60,111}\end{array}$ & $\begin{array}{l}\text { Inhalation may cause } \\
\text { respiratory irritation }\end{array}$ \\
\hline Caffeine & $\mathrm{Tea}^{106}$ & Not toxic \\
\hline Catechol & $\begin{array}{c}\text { Tea - pyrolysis of catechin, }{ }^{94} \text { present } \\
\text { in black tea }\end{array}$ & $\begin{array}{l}\text { Tumour promoter, } \\
\text { increases cell } \\
\text { metastasis }\end{array}$ \\
\hline Hydroquinone & $\begin{array}{l}\text { Tea - pyrolysis product from } \\
\text { lignin }^{112}\end{array}$ & $\begin{array}{l}\text { Tumour promoter, } \\
\text { increases cell } \\
\text { metastasis }\end{array}$ \\
\hline Succinimide & $\begin{array}{l}\text { Tea - pyrolysis product } \\
\text { glutamic acid }^{114}\end{array}$ & $\begin{array}{l}\text { Inhalation may cause } \\
\text { respiratory irritation, } \\
\text { compound is not toxic }^{115}\end{array}$ \\
\hline Theobromine & $\mathrm{Tea}^{106}$ & Not toxic \\
\hline Triacetin & $\begin{array}{l}\text { Cellulose acetate cigarette } \\
\text { filters }{ }^{103-105} \text { (TPM analysis) }\end{array}$ & - \\
\hline
\end{tabular}


Table 12. Nicotine in Trap Residue - Methanol Trap

\begin{tabular}{llll}
\hline & $\mathrm{mg} / \mathrm{g}$ & STD & Std. Error \\
\hline Winfield Cigarette $^{\text {t/ }}$ & 3.96568 & 0.74949 & 0.43273 \\
\hline Washed Tea Cigarette & 3.76561 & 1.97926 & 1.14276 \\
\hline Teabacco Cigarette $^{\text {t }}$ & 2.00381 & 0.371 & 0.21421 \\
\hline Unwashed Tea Cigarette $^{*}$ & 22.23242 & 0.62352 & 0.36 \\
\hline
\end{tabular}

This article is protected by copyright. All rights reserved. 
Table 13. Nicotine Extracted by Smoking Product - Methanol Trap

\begin{tabular}{|c|c|c|c|}
\hline & $\mathrm{mg} / \mathrm{g}$ & STD & Std. Error \\
\hline Winfield Cigarette ${ }^{\text {tX }}$ & 0.08495 & 0.0065 & 0.00375 \\
\hline Washed Tea Cigarette $^{*}$ & 0.09159 & 0.08352 & 0.04822 \\
\hline Teabacco Cigarette ${ }^{t}$ & 0.01368 & 0.00488 & 0.00282 \\
\hline Unwashed Tea Cigarette* & 0.52299 & 0.04087 & 0.0236 \\
\hline
\end{tabular}

This article is protected by copyright. All rights reserved. 


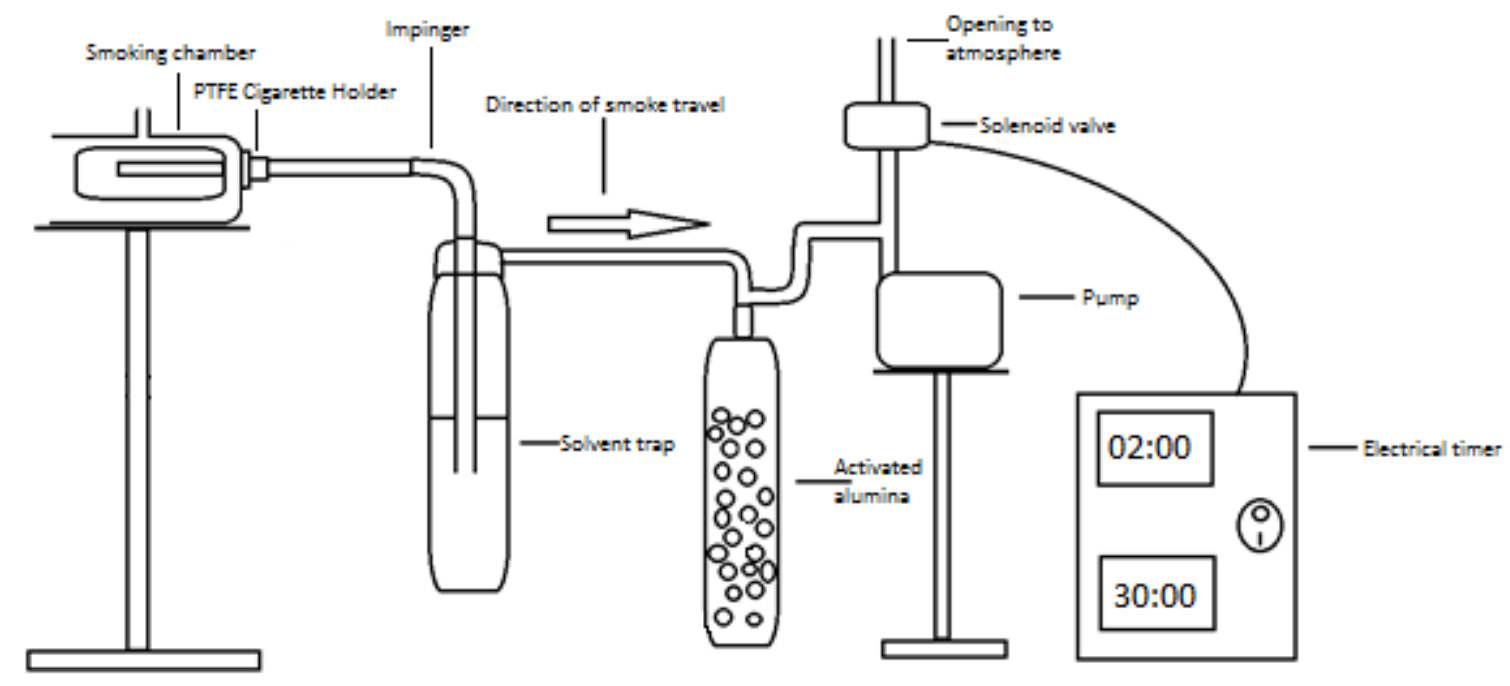

Figure 1. Schematic of the simple system used for the smoking of cigarettes. 


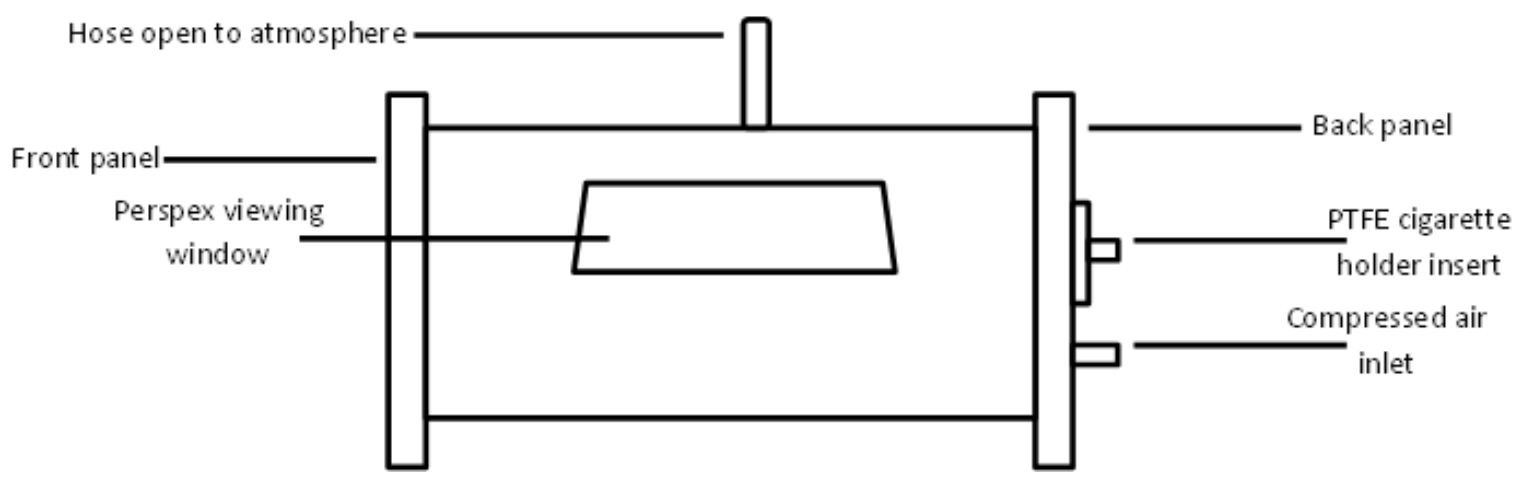

Figure 2. Side view of smoking chamber. 


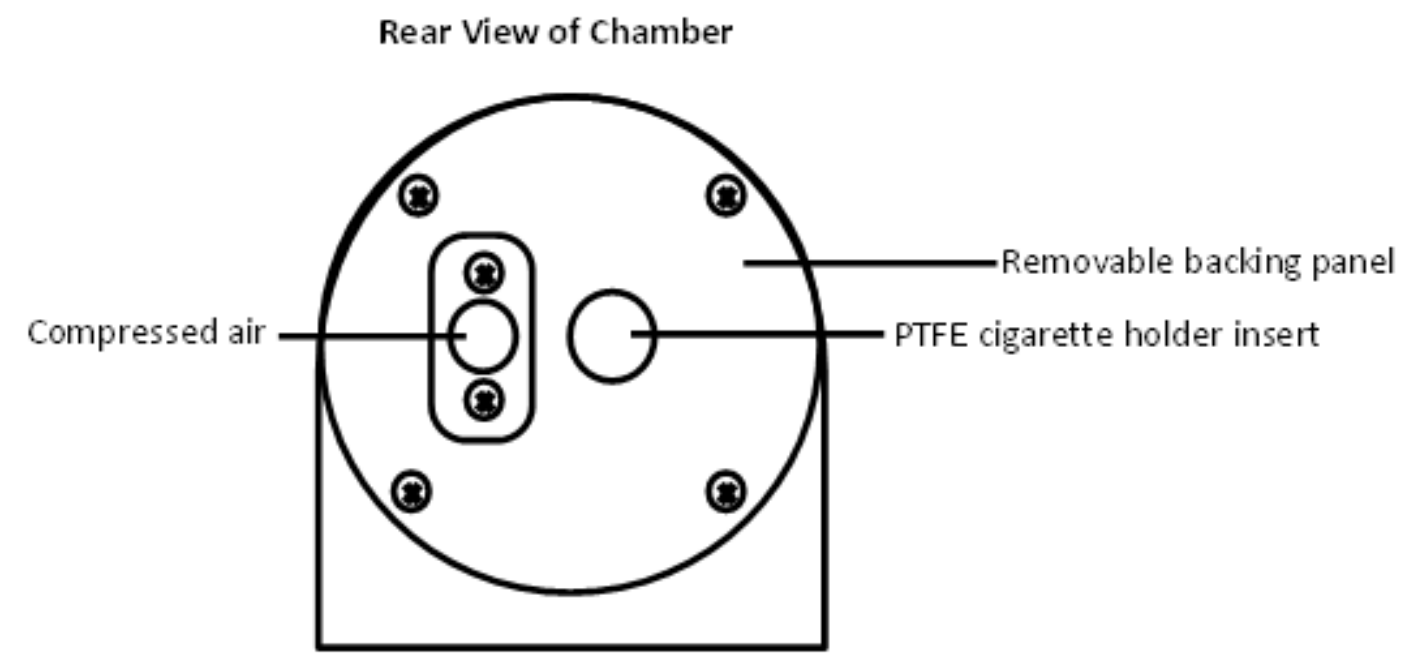

Figure 3. Rear view of smoking chamber. 
PTFE Cigarette Holder (Assembled -

Component $\mathrm{A}$ and $\mathrm{B}$

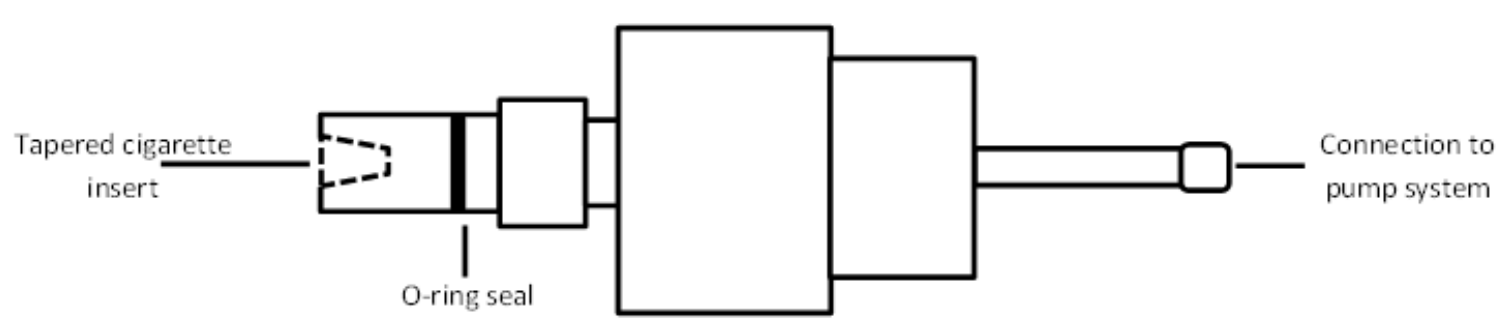

Figure 4. PTFE Cigarette Holder.

This article is protected by copyright. All rights reserved. 


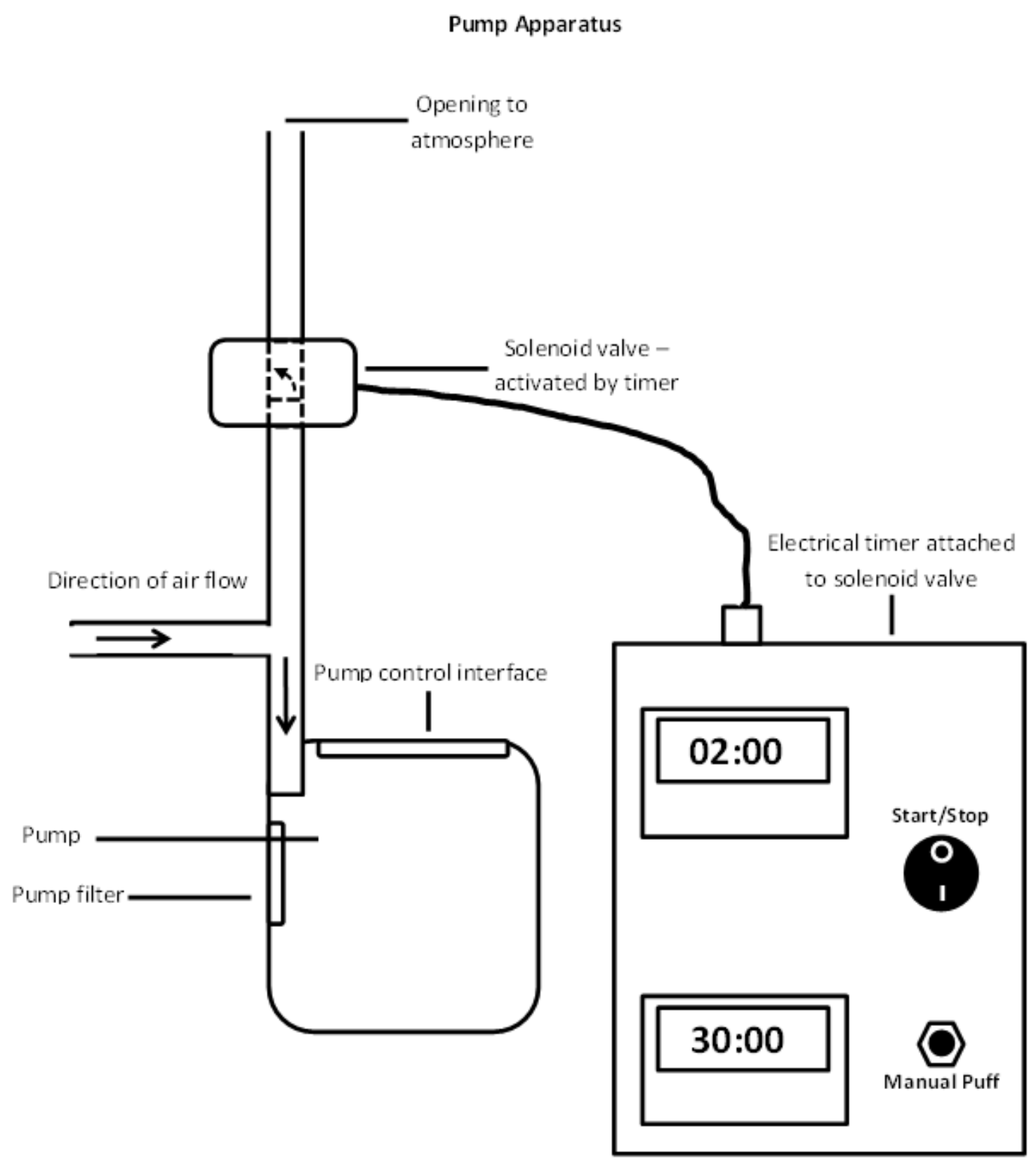

Figure 5. Air flow puff control mechanism. 


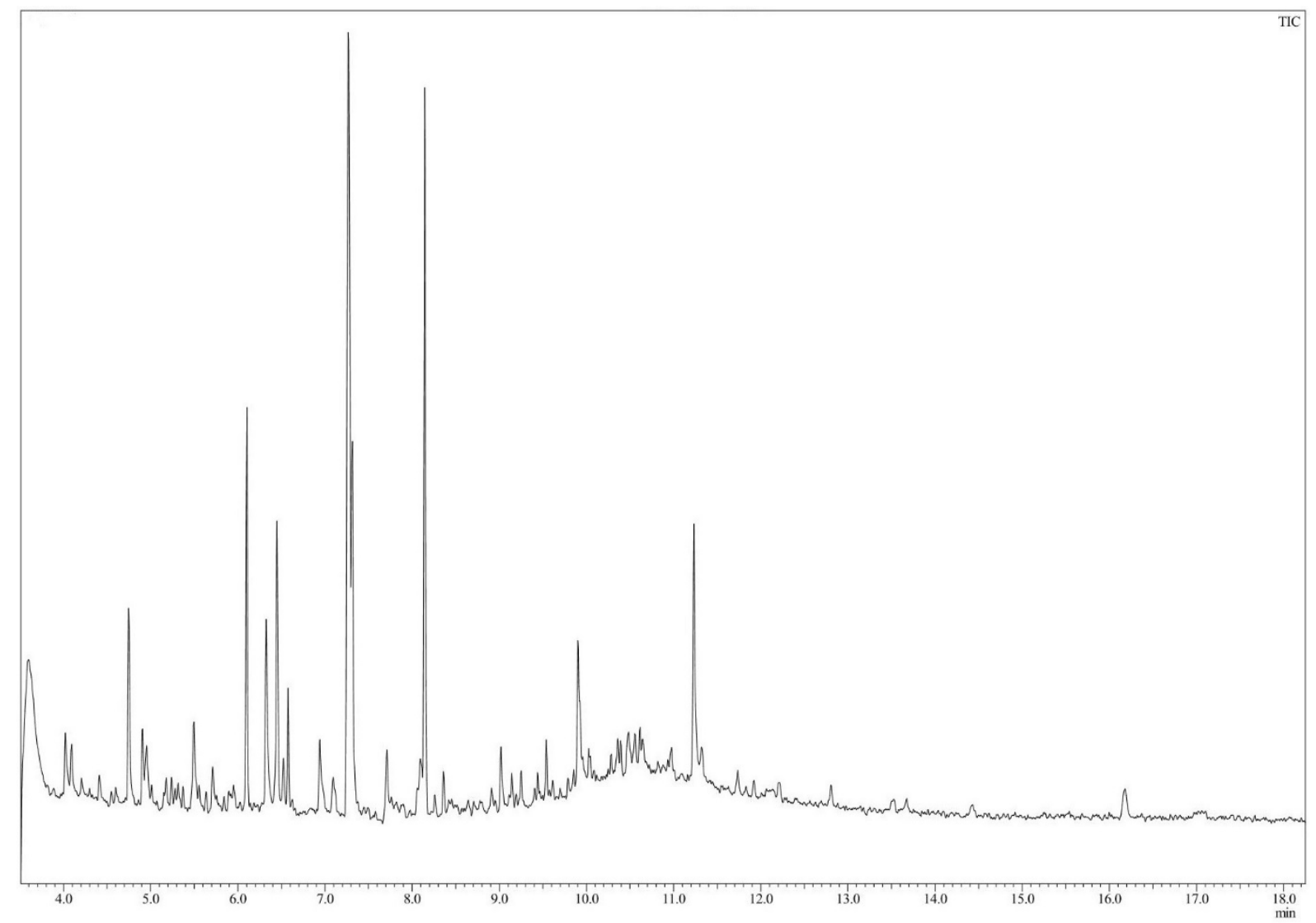

Figure 6. GC-MS Chromatogram of filtered washed tea in methanol.

This article is protected by copyright. All rights reserved. 


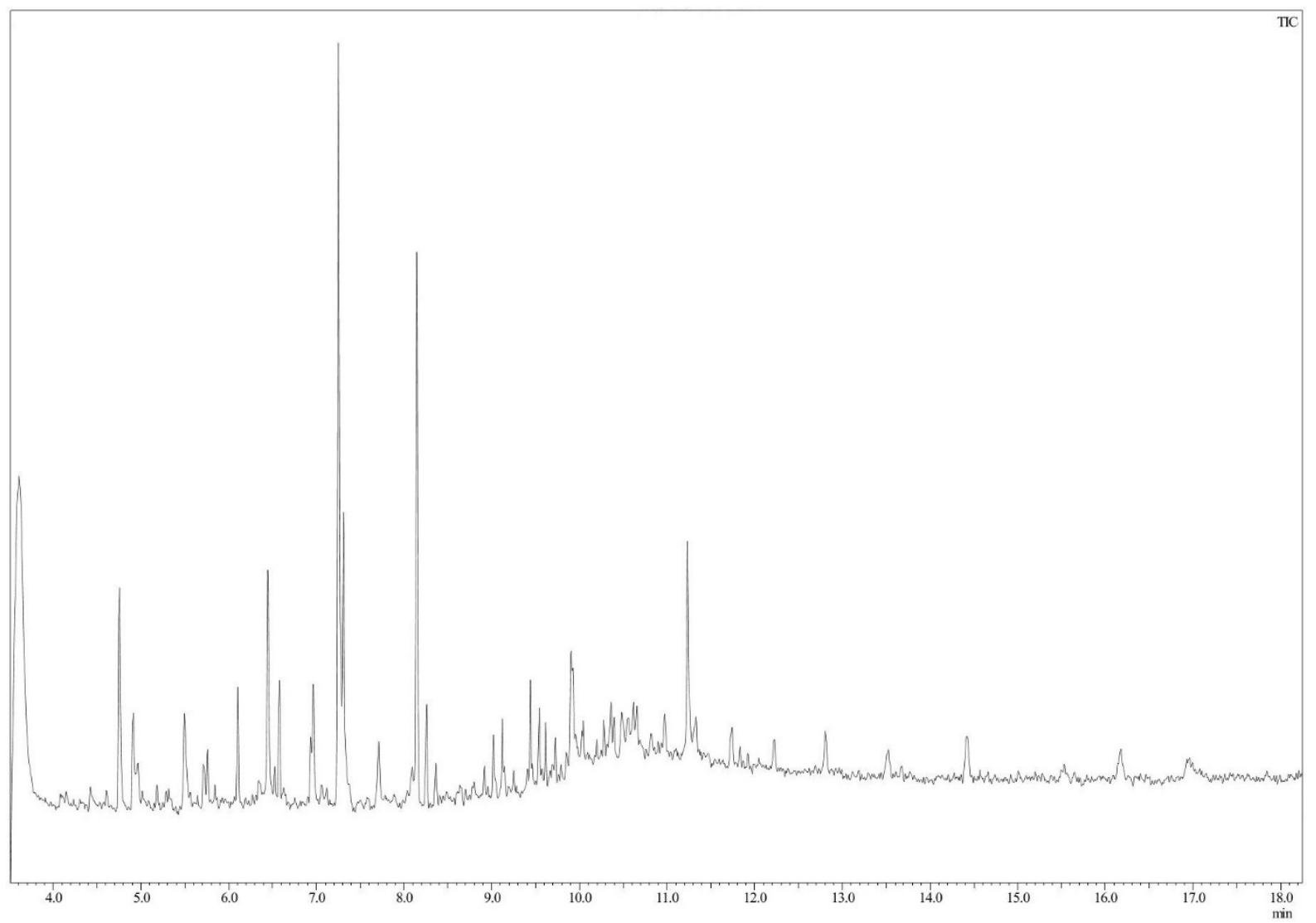

Figure 7. GC-MS Chromatogram of filtered washed tea in toluene. 
25

Nicotine content in Smoke Trap Residue

$\mathrm{mg} / \mathrm{g}$

20

10

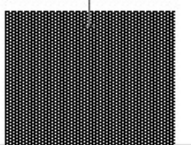

0

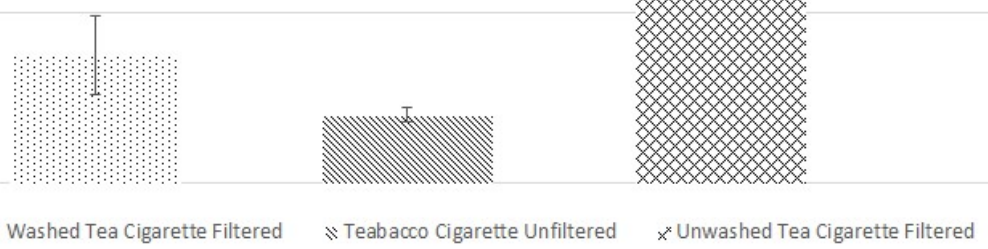

Figure 8. Nicotine in Smoke Trap Residue - Methanol Trap.

This article is protected by copyright. All rights reserved. 


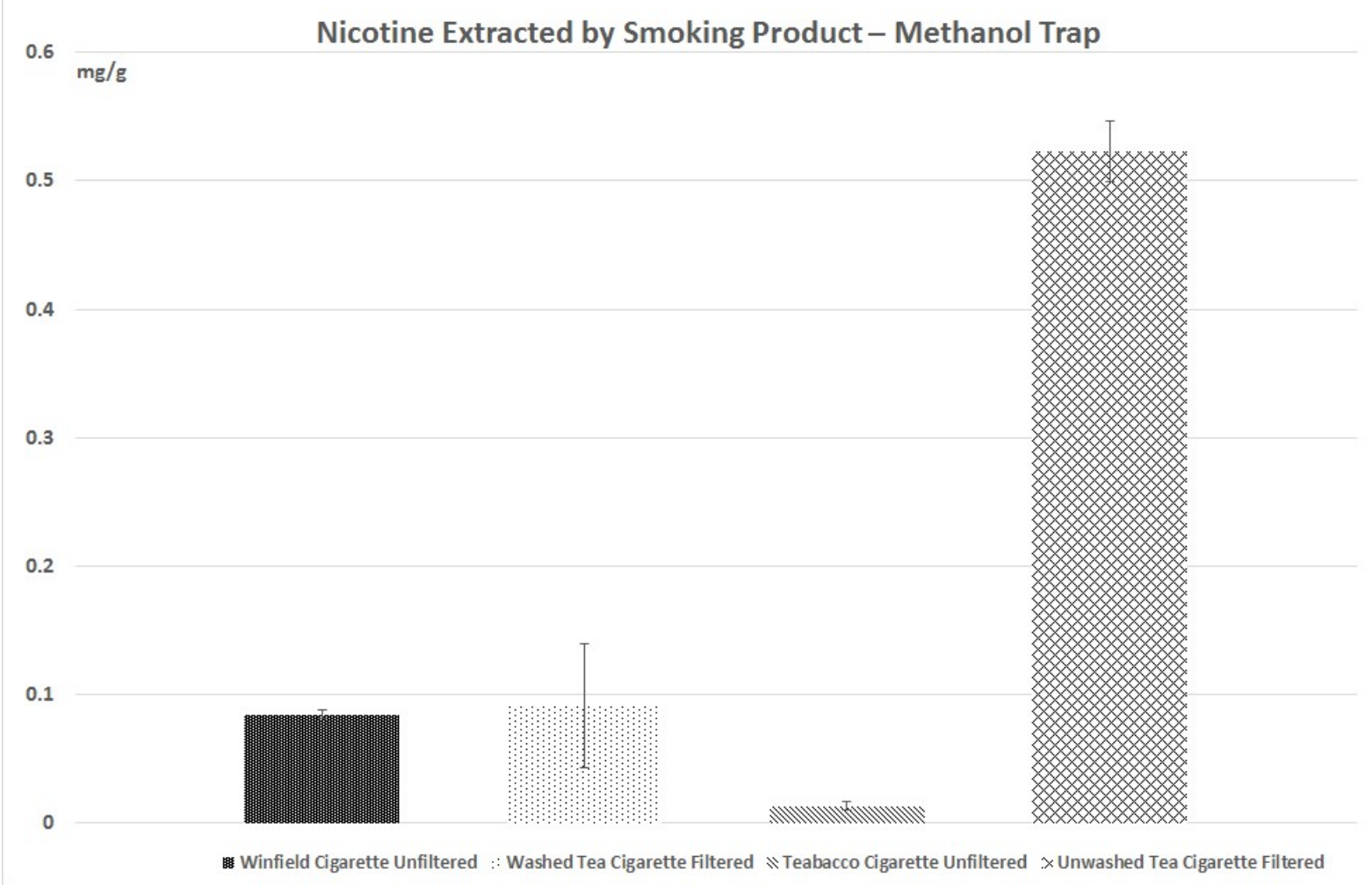

Figure 9. Nicotine Extracted by Smoking Product - Methanol Trap.

This article is protected by copyright. All rights reserved. 


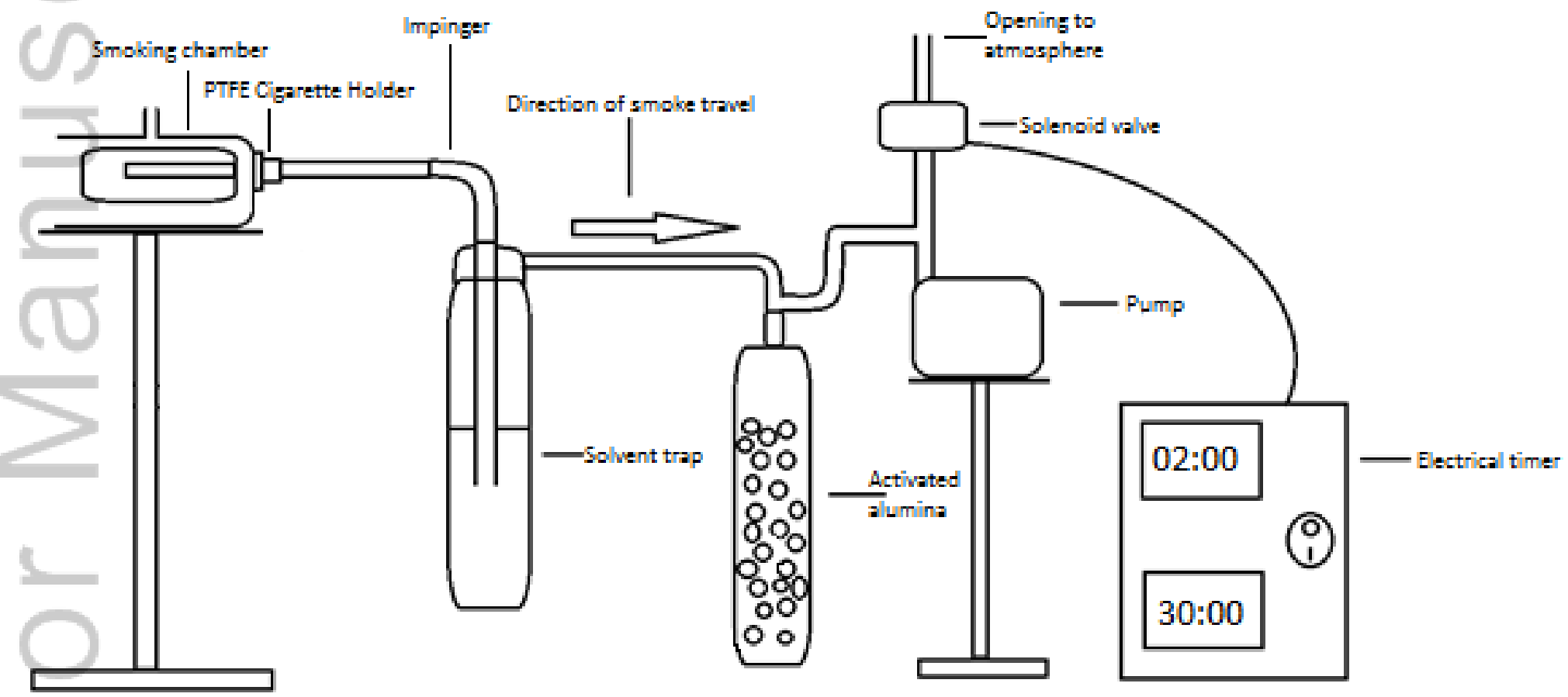

DTA_2471_F1.png

This article is protected by copyright. All rights reserved. 
Side View of Chamber

Hose open to atmosphere

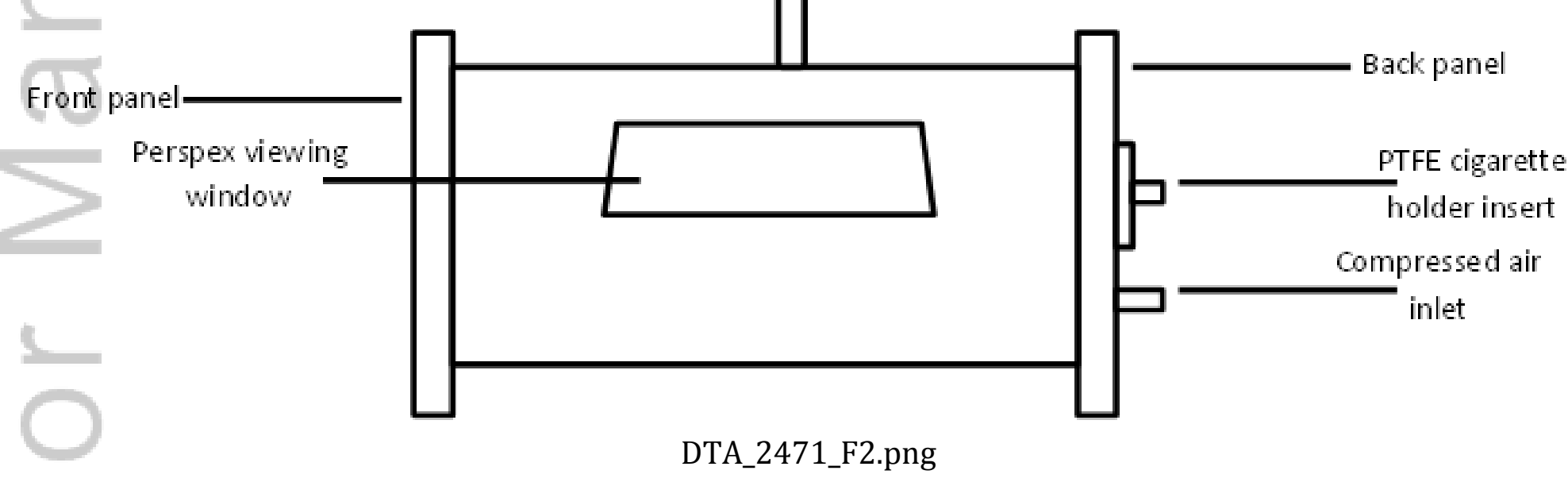

This article is protected by copyright. All rights reserved. 
PTFE Cigarette Holder (Assembled Component A and B)

Tapered cigarette insert

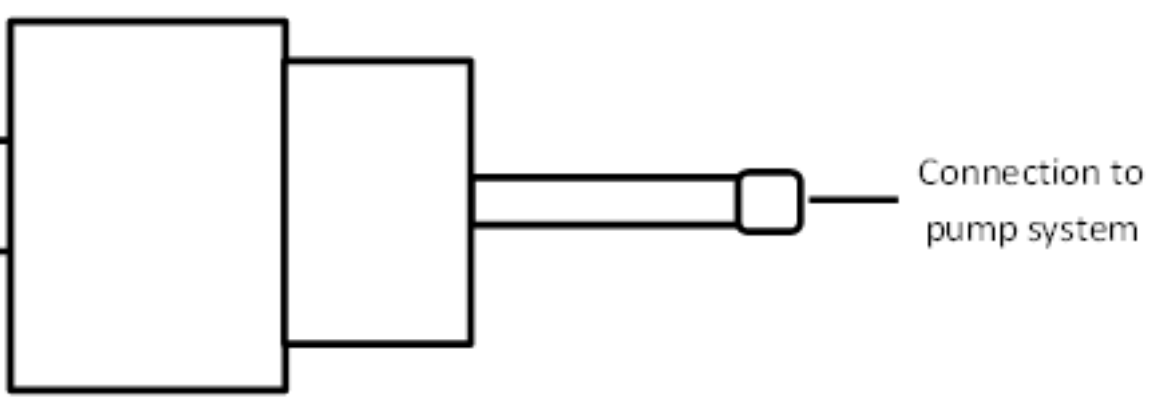

$$
\text { DTA_2471_F4.png }
$$

This article is protected by copyright. All rights reserved. 


\section{Pump Apparatus}

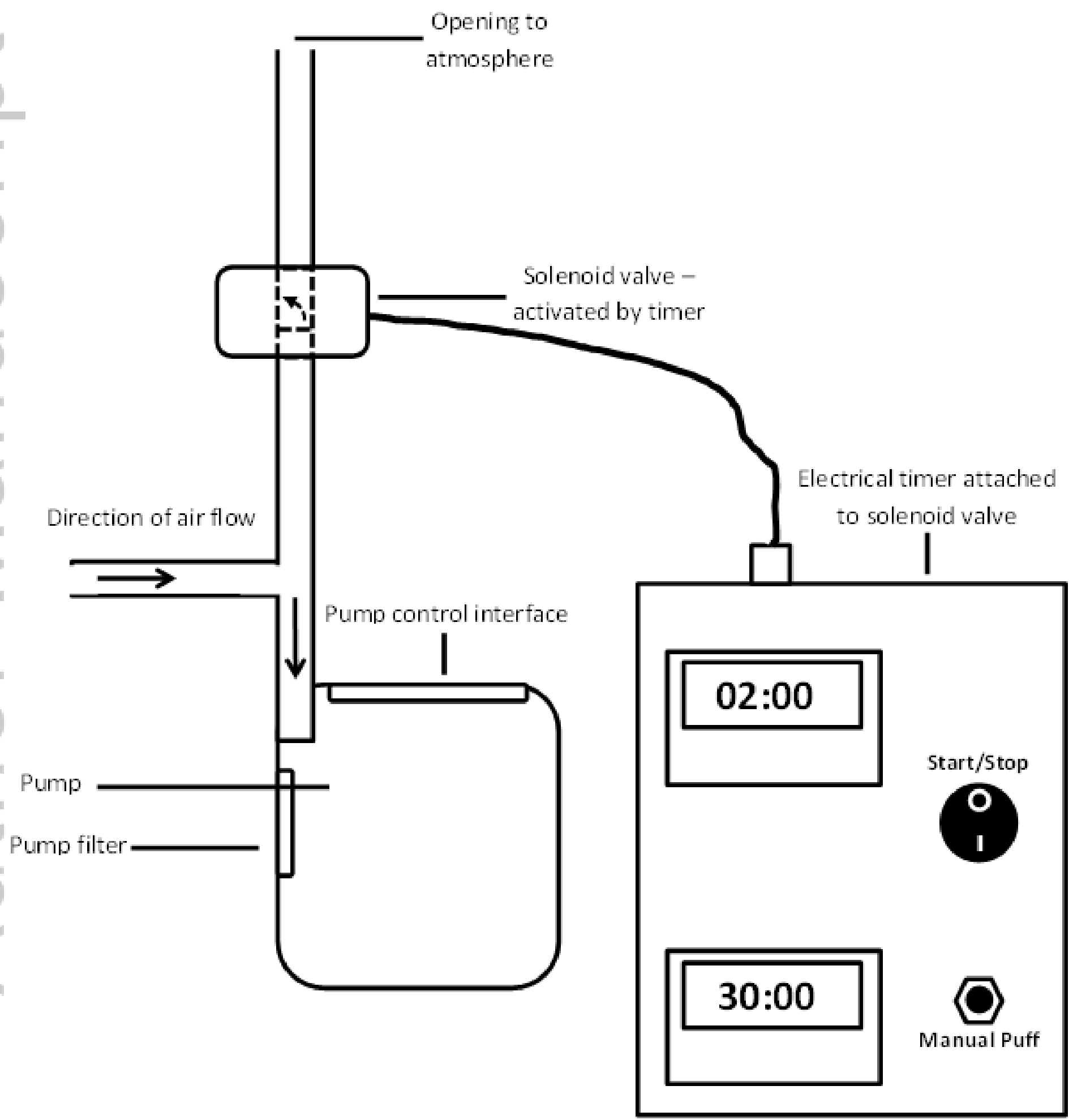

DTA_2471_F5.png 


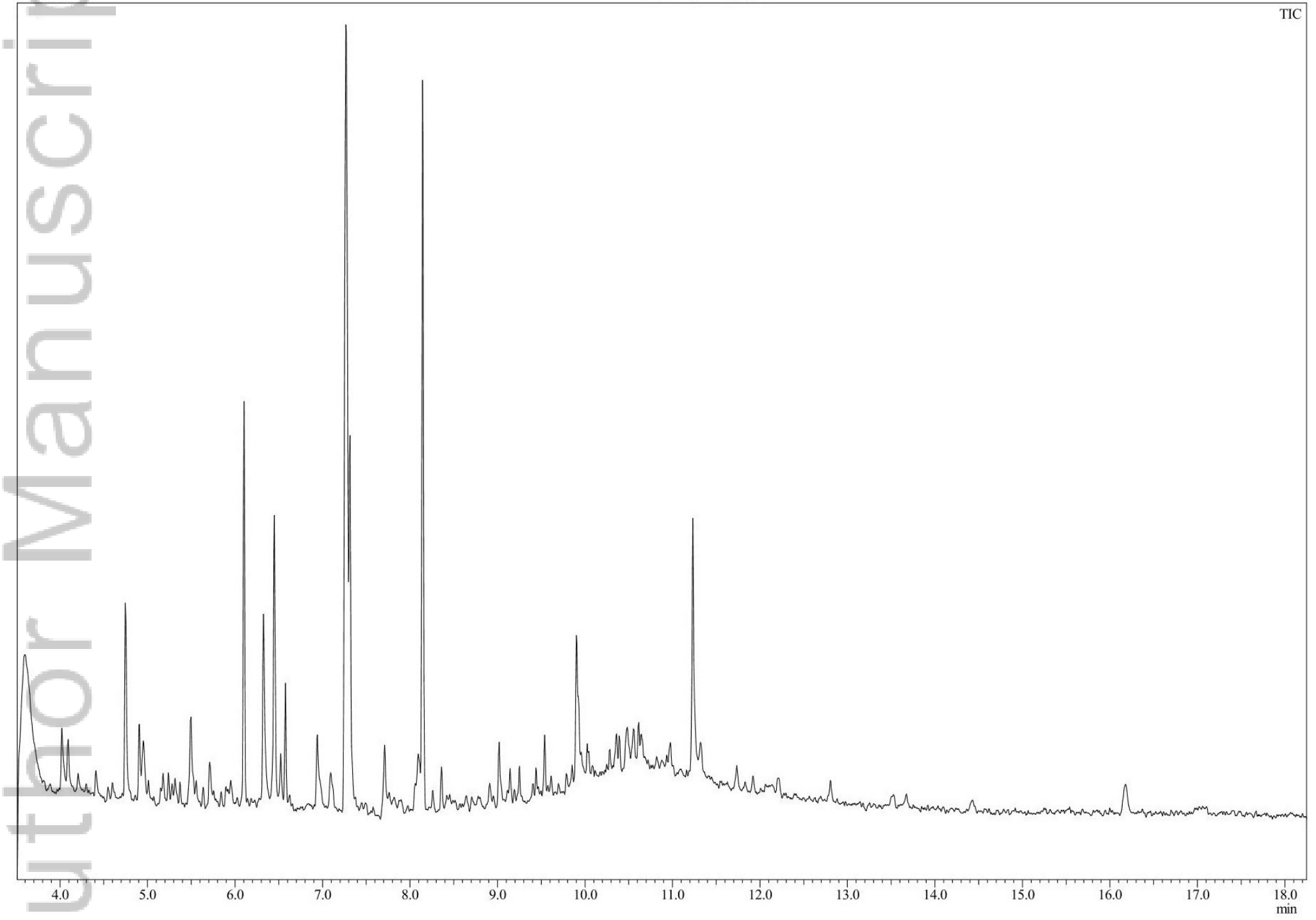

DTA_2471_F6.jpg

This article is protected by copyright. All rights reserved. 


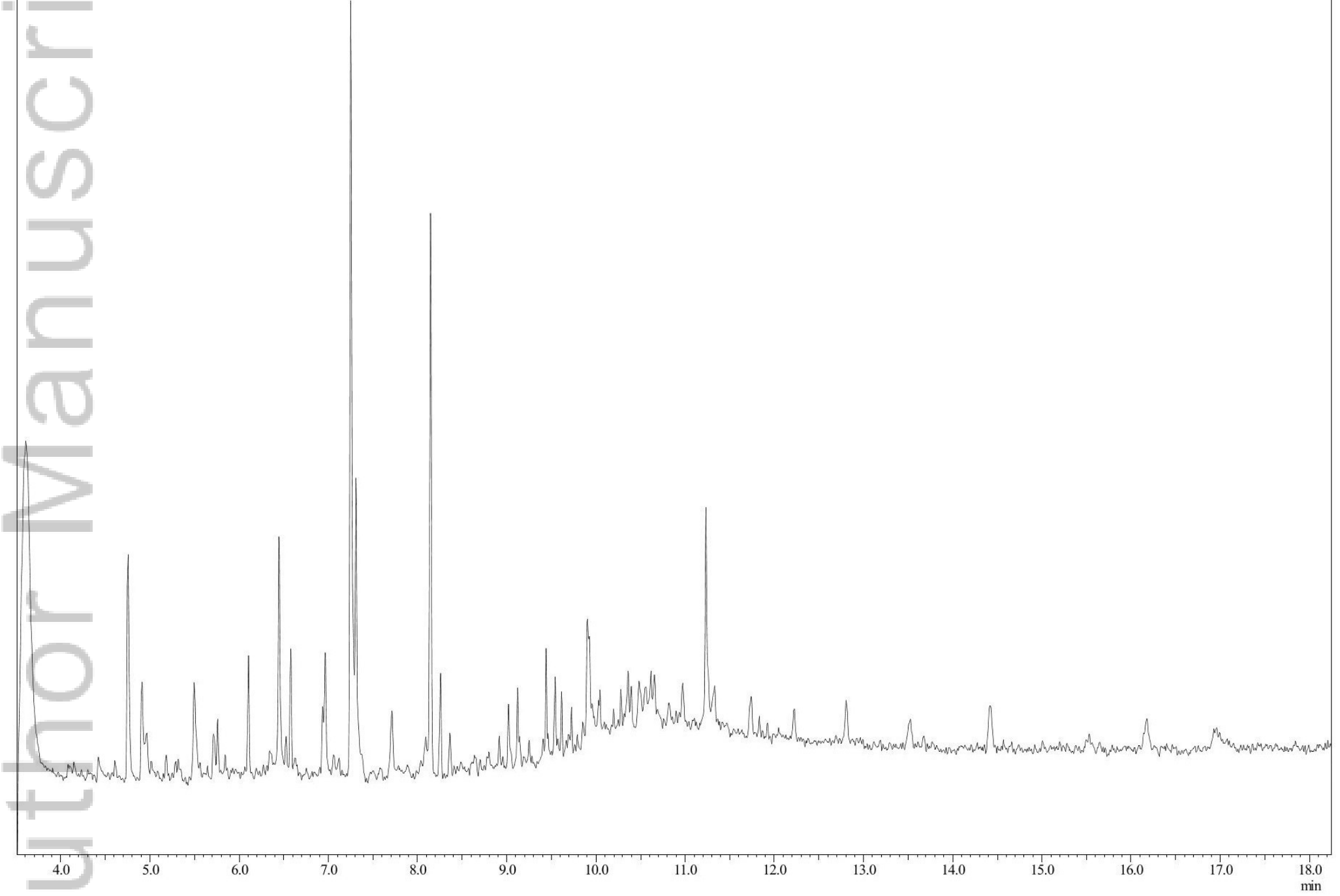

DTA_2471_F7.jpg

This article is protected by copyright. All rights reserved. 
$25 \mathrm{mg} / \mathrm{g}$

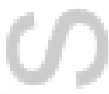

20

15

15

$\sqrt{2}$
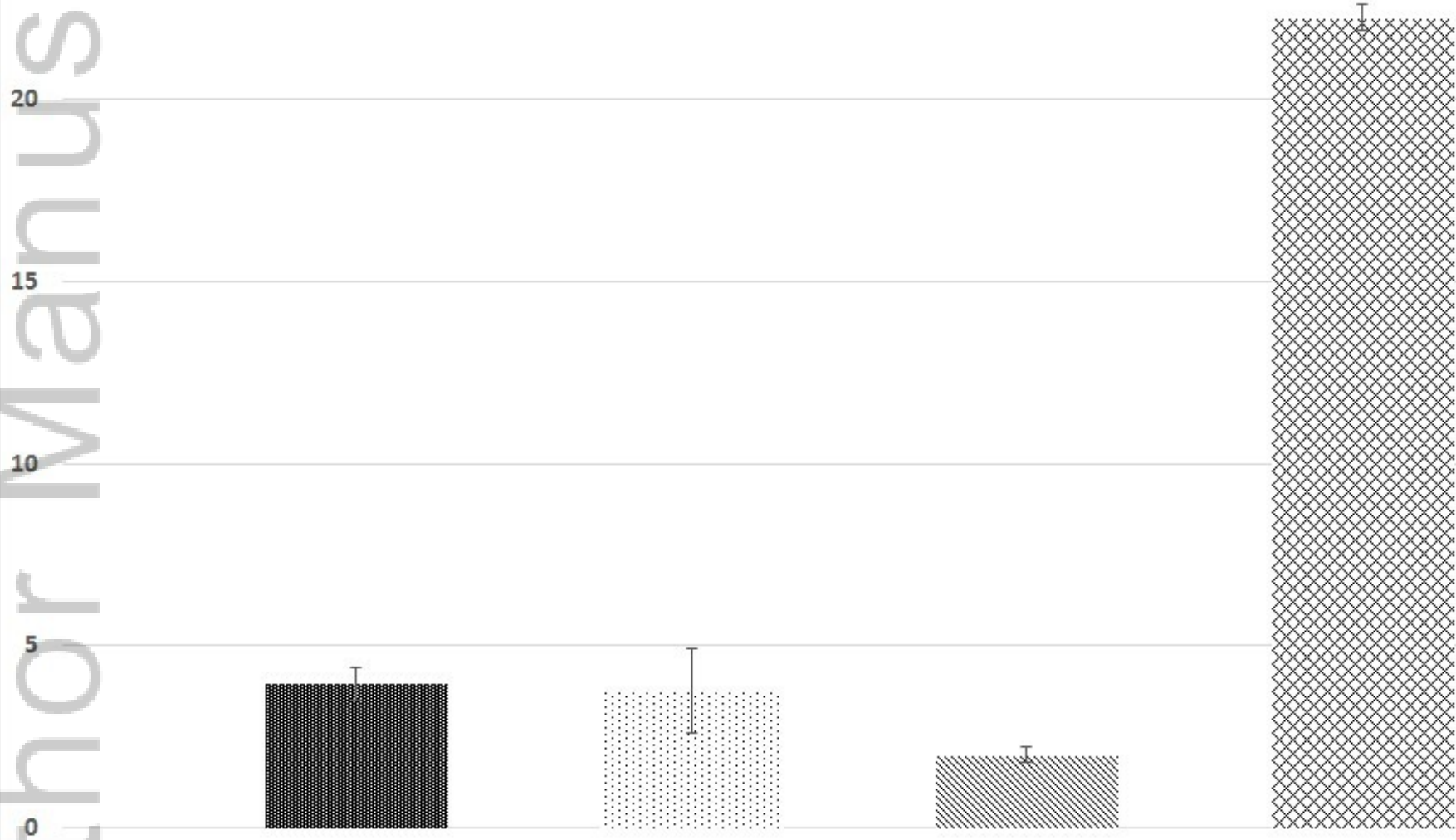

O1.

10

: Washed Tea Cigarette Filtered

« Teabacco Cigarette Unfiltered

* Unwashed Tea Cigarette Filtered

DTA_2471_F8.jpg

This article is protected by copyright. All rights reserved. 


\section{Nicotine Extracted by Smoking Product - Methanol Trap}

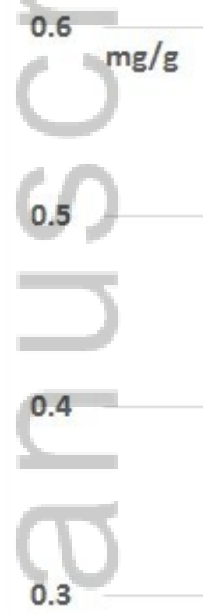

0.2

3

0.1

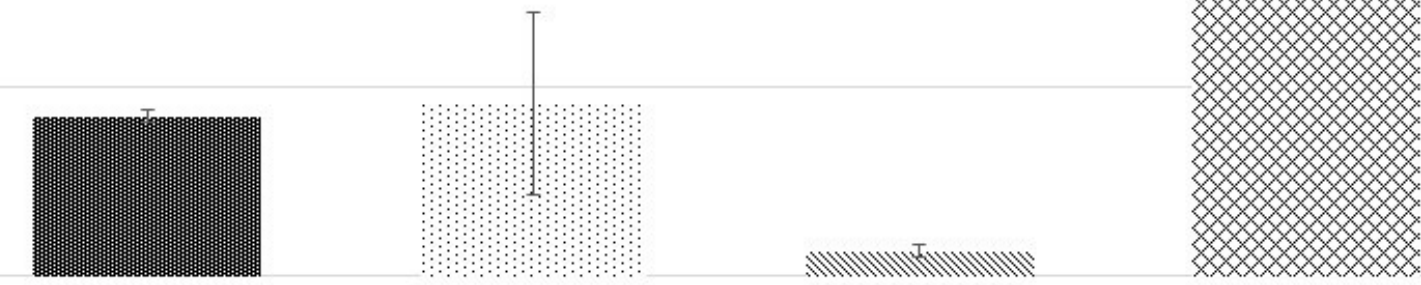

略 Winfield Cigarette Unfiltered $\quad:$ Washed Tea Cigarette Filtered $\leqslant$ Teabacco Cigarette Unfiltered $\times$ Unwashed Tea Cigarette Filtered

DTA_2471_F9.jpg

This article is protected by copyright. All rights reserved. 


\section{University Library}

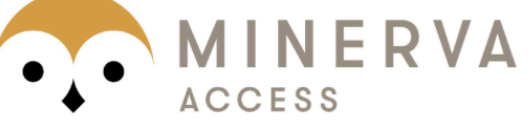

A gateway to Melbourne's research publications

Minerva Access is the Institutional Repository of The University of Melbourne

Author/s:

Mitchell, C;Puljevic, C;Coomber, R;White, A;Cresswell, SL;Bowman, J;Kinner, SA

Title:

Constituents of "teabacco": A forensic analysis of cigarettes made from diverted nicotine replacement therapy lozenges in smoke-free prisons

Date:

2019-01-01

\section{Citation:}

Mitchell, C., Puljevic, C., Coomber, R., White, A., Cresswell, S. L., Bowman, J. \& Kinner, S. A. (2019). Constituents of "teabacco": A forensic analysis of cigarettes made from diverted nicotine replacement therapy lozenges in smoke-free prisons. DRUG TESTING AND ANALYSIS, 11 (1), pp.140-156. https://doi.org/10.1002/dta.2471.

Persistent Link:

http://hdl.handle.net/11343/284343 